\title{
Reinsurance demand and liquidity creation: A search for bi-causality ${ }^{1}$
}

\author{
Denise Desjardins², Georges Dionne ${ }^{2}$, and N'Golo Koné ${ }^{3}$
}

19 June 2020

\begin{abstract}
We analyze the relationship between insurers' liquidity creation and reinsurance demand. Early theoretical contributions on liquidity creation propose that financial institutions enhance economic growth by creating liquidity in the economy. Liquidity creation means financing relatively illiquid assets with relatively liquid liabilities. However, liquidity creation exposes insurers to financial risks. There is a trade-off between getting higher returns on risky investments and being able to compensate clients at a low cost when unexpected claims happen. Unexpected claims can be protected by reinsurance, which introduces a second trade-off between reinsurance demand and liquidity creation. This trade-off can be more important for insurers that have fewer diversification opportunities. Our main empirical results, from regularized GMM and ML-SME methods of estimation, show similar positive bi-causal effects between liquidity creation and reinsurance demand for small insurers (22\% of insurance activity). The link between the two activities is not significant for large insurers (60\% of insurance activity). We obtain mixed results for medium insurers. In all estimations, the standard GMM model is rejected.
\end{abstract}

Keywords: Reinsurance demand; liquidity creation; causality; bi-causality; Generalized Method of Moments; Maximum Likelihood; Structural Equation Modeling.

\footnotetext{
${ }^{1}$ This research was financed by the Foundation SCOR for science, a research foundation belonging to the SCOR Group, and by SSHRC Canada. We received very useful comments that improved the paper from the participants of the following conferences: 2018 Annual Seminar of the European Group of Risk and Insurance Economists, 2018 Annual Meeting of the Canadian Economics Association, 2017 Annual Meeting of the American Risk and Insurance Association and, more particularly, from James Garven and Pierre Picard.

${ }^{2}$ Canada Research Chair in Risk Management, HEC Montréal.

${ }^{3}$ Department of Economics, Université de Montréal.
} 


\section{Introduction}

This paper analyze the relationship between insurers' liquidity creation and reinsurance demand. The empirical measure of liquidity creation was developed for banks by Berger and Bouwman (2009), who distinguish two important bank activities: liquidity creation and risk transformation. Insurers also actively transform risk, but the extent of their engagement in liquidity creation is less clear. Because liquidity creation is a risky activity, it may affect the demand for reinsurance.

Early theoretical contributions on liquidity creation (Bryant, 1980; Diamond and Dybvig, 1983) propose that financial institutions enhance economic growth by creating liquidity in the economy. Liquidity creation means financial institutions invest in relatively illiquid assets with relatively liquid liabilities. Banks provide illiquid debt to borrowers and receive liquid deposits from depositors. In a world without financial intermediaries, depositors would hold the illiquid debt (Bouwman, 2014). By creating liquidity for their borrowers, financial institutions become less liquid but increase liquidity in the economy. ${ }^{4}$

Banks also use equity obtained from shareholders to finance loans. Holmstrom and Tirole (1998) and Kashyap et al. (2002) suggest that banks create liquidity off the balance sheet through loan commitments and similar claims to liquid funds. Berger and Bouwman (2009) show that large banks created most of the banking liquidity in the United States over the 1993-2003 period. These banks were responsible for $81 \%$ of industry liquidity creation yet comprised only $2 \%$ of the sample observations. Bank liquidity creation is shown to be positively correlated with bank value.

Berger and Bouwman (2009) also find that the relationship between liquidity creation and capital is positive for large banks and negative for small banks. For small banks, higher capital ratios often shift funds from deposits to bank capital. Given that deposits are liquid and bank equity is illiquid, there is a reduction in overall liquidity creation when the capital ratio is higher. Large banks use liabilities that are less liquid than deposits to create liquidity, suggesting that an increase in capital may lead to a drop in other liabilities rather than in deposits. Thus, capital is more likely to crowd out deposits for small banks than for large banks.

\footnotetext{
${ }^{4}$ Bai et al. (2018) develop a similar index of liquidity creation for banks but its interpretation is converse to that of Berger and Bouwman (2009) in that creating liquidity makes banks more liquid. In this research, we use Berger and Bouwman's (2009) definition.
} 
Choi et al. (2013) are the first to measure liquidity creation in the US Property and Liability insurance industry (P/L insurance industry). They use Berger and Bouwman's (2009) approach and find that insurers destroy liquidity rather than create it. It seems that insurers' liabilities are less liquid, and their assets are more liquid. Regulators ask insurers to keep a significant amount of reserves and assets that are easy to liquidate. In their data, larger insurers account for more than $55 \%$ of liquidity de-creation, yet they represent only $3 \%$ of the insurance industry. One explanation for the difference between banks and insurers is the ratio of equity to assets. In Choi et al.'s (2013) data, this ratio for insurers is equal to $45 \%$, compared with about $10 \%$ for banks in Berger and Bouwman's (2009) study. More recently, Alhassan and Biekpe (2019) obtained similar results for the insurance industry in South Africa. However, all these relationships are not causal. There is one exception for the banking industry. Horváth et al. (2012) obtained a Granger causal negative relationship between bank capital and liquidity creation. But their liquidity creation categories are based on asset and liability maturities instead of types of assets, as in the literature and in this study.

An insurer with a high level of liquidity creation will hold more illiquid assets and will be considered riskier by the regulator and possibly the policyholders. If a riskier insurer receives more claims than expected, it may have to sell illiquid assets quickly at a lower price to pay the corresponding claims. There is thus a trade-off between getting higher returns on risky investments and being able to compensate clients at a low cost when unexpected claims happen (Cummins et al., 2008). However, unexpected claims can be protected by reinsurance, which introduces a second trade-off between reinsurance demand and liquidity creation. This trade-off can be more important for smaller insurers that have fewer diversification opportunities.

The goal of this study is to analyze the causal relationship between insurers' liquidity creation and their demand for reinsurance. Do insurers that take more risk in creating liquidity buy more reinsurance to cover this risk? And conversely, do insurers that buy more reinsurance take more risks in illiquid assets with higher returns?

Our main contribution is to investigate the causality links between liquidity creation and reinsurance demand in a dynamic panel where the number of observations is quite large and the number of periods is moderately large. We investigate two methods of estimation with fixed effects: the Generalized Method of Moments (GMM) and the Maximum Likelihood estimation of Structural Equation Modeling (ML-SEM). Since the seminal work of Arellano and Bond (1991), 
the GMM procedure has become a very popular method for estimating parameters with dynamic panel data and individual fixed effects. However, when the number the moment conditions is very large in a panel moderately large, bias estimates can be obtained with the standard GMM estimation method, particularly when the autoregressive parameter of the dependent variable is close to unity (Blundell and Bond, 1998; Doran and Schmidt, 2006; Okui, 2009). The covariance matrix of instruments (lagged values of explanatory variables) can considerably impact the properties of the estimators. Carrasco and Nayihouba (2019) propose a regularization approach based on different procedures for inverting the covariance matrix of instruments and reduce the potential bias verified with the standard GMM method. We apply two of their procedures in our estimations obtained from a dynamic panel of 34,376 observations over 23 years. We verify that the standard GMM approach underestimates the cross-effects between reinsurance demand and liquidity creation. We always reject the standard GMM model whatever the length of the panel and the number of observations.

For robustness, we estimate the Maximum Likelihood with the Structural Equation Modeling (ML-SEM) method. This method may fail to converge when the number of periods is moderately large, as in our sample. Therefore, we restrict our application to a subset of variables that improve the estimations. When we use the same econometric specification with the same data, the regularized GMM and the ML-SEM methods of estimation yield the same results. We obtain bi-causal effects between liquidity creation and reinsurance demand for small insurers. The links between the two activities are not significant for large insurers and are mixed for medium insurers.

We present the basic framework of liquidity creation for insurers in Section 1. We then describe our data and basic econometric model. Preliminary results of the standard least-squares model are discussed in Section 4. Causality between liquidity creation and reinsurance demand is investigated in Sections 5 and 6. An analysis of control variable results is provided in Section 7. The last section concludes the paper. 


\section{Liquidity creation: the basic framework}

Insurers' liquidity creation framework is analyzed in three steps. First, we categorize assets, liabilities and surplus into liquid, semi-liquid and illiquid items. This classification is based on cost and time to meet contractual obligations. A financial institution will create one dollar of liquidity in the economy by transforming one dollar of liquid liabilities into one dollar of illiquid assets, or will create one dollar of liquidity de-creation by transforming one dollar of liquid assets into one dollar of illiquid liability or surplus. Transforming one dollar of liquid (illiquid) assets into one dollar of liquid (illiquid) liabilities (or the converse) is considered neutral with respect to liquidity creation. Shorter maturities are also considered more liquid than longer maturities in the literature. However, consistent with Berger and Bouwman (2009), we distinguish categories of assets and liabilities as opposed to their corresponding maturities.

We can assign weights to the different assets, liabilities, surplus, and off-balance sheet positions according to their degree of relative liquidity creation. The weights are based on liquidity availability. We then add up the different relative measures to obtain an index of liquidity creation for a particular financial institution in a given period.

We apply positive weights to both illiquid assets and liquid liabilities. These weights are presented in Table 1 for an insurer's balance sheet. Accordingly, when one dollar of tax (liquid liability) is used to finance one dollar of real estate (illiquid asset), liquidity is created. With the same reasoning, we give negative weights to liquid assets, illiquid liabilities, and equity, so that when illiquid liabilities or equity is used to finance liquid assets (such as loss reserves within one year), liquidity is destroyed.

Let us consider in detail two examples of transformation applied to insurance. Based on the above rules, as shown in Table 1 , we can assign a weight of $1 / 2$ to both illiquid assets and liquid liabilities, and a weight of $-1 / 2$ to both liquid assets and illiquid liabilities. Thus, when one dollar of liquid liabilities (such as unearned premiums) is used to finance one dollar of illiquid assets (such as real estate), liquidity creation equals $1 / 2 \times \$ 1+1 / 2 \times \$ 1=\$ 1$. In this case, maximum liquidity (\$1) is created in the economy. Intuitively, the weight of $1 / 2$ applies to both illiquid assets and liquid liabilities, because the amount of liquidity created is only determined by $1 / 2$ of the source of the funds, but both entries are needed to create liquidity. Similarly, when one dollar of illiquid 
liabilities or equity is used to finance one dollar of liquid assets (such as treasury securities), liquidity creation equals $-1 / 2 \times \$ 1-1 / 2 \times \$ 1=-\$ 1$; maximum liquidity is thus destroyed.

[Table 1 about here]

\section{Data and variables}

We focus on demand for reinsurance and liquidity creation in the U.S. property-liability insurance industry. We use the National Association of Insurance Commissioners' (NAIC) annual financial statement data for U.S. property-liability insurance companies. Our period of data ranges from 1993 to 2014, which gives us coverage of the 2007-2009 financial crisis period.

Several data exclusion criteria are applied. We first remove general insurers that report non-positive total admissible assets and premiums. We exclude insurers reporting a value outside of the 0 and 1 range for the ratio of reinsurance demand. The observations are winsorized at the 1 and 99 percent levels to remove the potential effects of outliers. In order to estimate fixed-effect regressions with lagged variables, firms with only one year of observation are also removed from the sample.

The resulting sample consists of 34,376 firm-year observations from 2,792 non-life insurers. The sample includes insurers that entered or left the market during the study period. We thus have an unbalanced data panel to permit a comprehensive evaluation of the U.S. propertyliability insurance industry.

\section{Dependent variables}

We use Reins to measure an insurer's demand for reinsurance. It is defined as (affiliated reinsurance ceded + non-affiliated reinsurance ceded) / (direct business written plus reinsurance assumed). We use Liquid to measure an insurer's liquidity creation ratio. It is defined as LC/total admitted assets, where LC is defined as in Table 1 (step 3).

\section{Endogenous variables}

Insurers' liquidity creation may represent an endogenous influence on demand for reinsurance. An insurer's liquidity creation may influence its demand for reinsurance, and the reverse causality from reinsurance purchase to liquidity creation may also exist. Our main objective is to identify the true causal relationships between the two activities. 
We treat liquidity creation as an endogenous variable in the reinsurance demand equation. An insurer with a high level of liquidity creation for the economy is considered riskier for policyholders because it holds more illiquid assets or has a large amount of liquid liabilities. We also consider the variable Reins as an endogenous variable in the liquidity creation equation in order to test for simultaneous causality between the two activities. An insurer having access to more reinsurance can make more long-term investments with higher returns in the economy and increase liquidity creation.

\section{Control variables}

Table 2 summarizes the definitions and construction of the following control variables.

\section{Insurance leverage ratio}

As a proxy for the insurance leverage ratio, we consider the direct business written to surplus. Garven and Lamm-Tennant (2003) and Cole and McCullough (2006) predict a positive relationship between the insurance leverage ratio and demand for reinsurance. A positive relationship between the two variables would suggest that firms that write more business relative to surplus would have a greater need for reinsurance because they have a higher probability of insolvency, and thus higher expected bankruptcy costs (Carson and Hoyt 1995; Shiu, 2011). This variable is not used in the liquidity creation equation since insurance leverage is part of the definition of liquidity creation ratio.

Line of business, geographic and business mix concentration

Following Mayers and Smith (1990), Kim et al. (1996), Garven and Lamm-Tennant (2003) and Cole and McCullough (2006), we use three indexes of activity concentration: the line of business Herfindahl index as a proxy for line of business concentration, the geographic Herfindahl index as a proxy for geographic concentration in direct premiums written, and the business mix Herfindahl index to reflect the degree of concentration of the four major branches of a propertyliability insurance company, namely short- and long-term personal insurance and short- and longterm commercial insurance.

A higher value of the Herfindahl index indicates a more specialized (less diversified) company. The lowest level of concentration would indicate that the insurer's operation is well spread over various lines of business, states or business branches, while the highest level of 
concentration indicates that the insurer's operation is mainly devoted to a single line of business or a single state or business branch.

Line of business concentration is defined as the sum of the squares of the ratio of the dollar amount of direct business written in a particular line of insurance to the dollar amount of direct business across all lines of insurance (Mayers and Smith, 1990). Geographical concentration is defined as the sum of the squares of the ratio of the dollar amount of direct business in state $j$ to the total amount of direct business across all states. Business mix concentration is defined as the sum of the squares of the ratio of the dollar amount of direct business of a particular branch of a property-liability insurance company to the total amount of direct business.

The degrees of business concentration, geographic concentration and business mix concentration may influence the insurer's reinsurance decision. Insurers with higher concentration (less diversification) in a given line of business, or in a given geographic area, may have higher incentives to purchase more reinsurance. In contrast, the economic benefits of specialization can reduce the demand for reinsurance (Chang et al., 2013; Cole and McCullough, 2006; Mayers and Smith, 1990; Shiu, 2011; Wang et al., 2008).

Mayers and Smith (1990) examine the effects of the composition of a firm's portfolio of activities on demand for reinsurance. They observe that an increased concentration of activities increases cash flows volatility and the risk of bankruptcy. For these authors, reinsurance could be a solution to the risk of insolvency arising from this source. However, Shortridge and Avila (2004) state that reinsurers have more experience with a wide range of low probability events; they can provide valuable information on rating different lines of business. Thus, as insurers become less concentrated across lines of insurance, reinsurance services become more valuable. We suggest an ambiguous relationship between the different degrees of specialization and the demand for reinsurance. More concentrated insurers should be less active in liquidity creation because they are more exposed to unanticipated shocks.

\section{Regulatory pressure}

The firm's net premium-to-surplus ratio measures the adequacy of the insurers' surplus cushion, net of the premiums ceded to reinsurers' effects. The higher the ratio, the more risks the insurer bears in relation to the policyholders' surplus. The usual range for the ratio includes results up to 300 percent (NAIC, Insurance Regulatory Information System (IRIS) Ratios Manual, Edition 2014). We use a dummy variable equal to 1 if the firm's net premium-to-surplus ratio is greater 
than 300 percent. It is equal to zero otherwise. We predict a negative sign for the demand for reinsurance equation and a positive sign for liquidity creation.

\section{Liabilities to liquid asset ratio}

A firm's adjusted liability-to-liquid asset ratio is a measure of the insurer's ability to meet short-term obligations. Previous analysis has shown that many insurers that became insolvent reported an increasing liabilities to liquid asset ratio in the previous years. The usual range for the ratio includes results below 100 percent (NAIC, Insurance Regulatory Information System (IRIS) Ratios Manual, Edition 2014). We use a dummy variable equal to 1 if the firm’s adjusted liability to liquid asset ratio is greater than 100 percent. It is equal to zero otherwise. We predict a positive sign in the demand for reinsurance equation. ${ }^{5}$ This variable is not used for the estimation of the liquidity creation ratio since it is part of the dependent variable definition, as shown in Table 1.

\section{Reinsurance price}

Several studies use the economic loss ratio of the reinsurance industry to measure the price of reinsurance (Winter, 1994; Sommer, 1996; Weiss and Chung, 2004). This ratio is defined as net premiums written to the present value of incurred losses adjusted for underwriting expenses, loss adjustment expenses, and dividend payments. ${ }^{6}$ We predict a negative effect of this price variable on the demand for reinsurance and a positive effect for the liquidity creation ratio, which should be positively affected by the level of premiums written.

\section{Tax exemption}

Mayers and Smith $(1982,1990)$ are the first to introduce the tax argument in relation to reinsurance demand by insurance companies. The presence of carry-forward and carry-back tax rules can create some non-linearities in the tax function and justify risk management when the tax function becomes locally convex. More importantly, large losses can affect the marginal tax rate when the tax function is locally convex. If important losses reduce the marginal tax rate in these states of nature, reinsurance demand will reduce the expected pre-tax shield by attenuating the volatility of ex-ante losses as any risk management tool (Graham and Rodgers, 2002; Dionne and Triki, 2013; Dionne, 2019).

\footnotetext{
${ }^{5}$ Liu et al. (2016) consider another liquidity variable measured as the ratio of liquid assets (cash, bonds, and shares) to total assets.

${ }^{6}$ For a detailed discussion on constructing the ratio, see Winter (1994).
} 
We use Powell and Sommer’s (2007) estimation for tax exemption investment income relative to total investment income adjusted to reflect changes in the tax code since 1987. Tax treatment is estimated as follows: bond interest exempt from federal taxes plus 70 percent of dividends on common and preferred stock. We use tax exemption investment income as a proxy to capture the influence of expected tax liability and/or tax-favored assets. A positive relationship between the tax exemption factor and the demand for reinsurance is predicted because, as Garven and Lamm-Tennant (2003) assert, insurers can take advantage of reinsurance demand to offset the costs of huge unexpected losses and improve investment in tax-favored assets. However, the results obtained by Adams et al. (2008) and Shiu (2011) do not support the positive influence of tax exemption factors on demand for reinsurance. Investing in tax-favored assets should positively influence liquidity creation as well.

\section{Information asymmetry}

We use the volatility of ROE as a measure of information asymmetry (Cummins and Nini, 2002; Grubisic and Leadbetter, 2007). Scordis and Steinorth (2012) argue that reinsurance is purchased when information asymmetry is low. The greater the information asymmetry between the insurer and the reinsurer, the higher the effective price imposed by the reinsurer on the ceding insurer. Jean-Baptiste and Santomero (2000) show that eliminating the information asymmetry premium results in a lower effective reinsurance price, and in higher reinsurance purchases. Thus, as Garven and Lamm-Tennant (2003) confirm, low information asymmetry may be indicative of high use of reinsurance. We do not have a prediction for liquidity creation.

Two-year loss development

Potential financial constraints can influence the demand for reinsurance, as suggested by previous contributions (Petroni, 1992; Weiss et al., 2004; Grace, 1990; Christensen et al., 1999; Gaver and Paterson, 1999; Cole and McCullough, 2006; Wang et al., 2008). Chang (2015) expected a positive relationship between loss reserve and demand for reinsurance. In addition, Harrington and Danzon (1994) indicate that insurers may use reinsurance to hide their underreported claim liability and capital adequacy.

We used the two-year loss development variable to determine if adjustments to loss reserves affect the demand for reinsurance. Two-year loss development is defined as development in estimated losses and loss expenses incurred two years before the current year and prior year, 
scaled by policyholders' surplus. A positive effect on demand for reinsurance and a negative effect on liquidity creation is predicted.

New York license

A dummy variable equal to 1 if the insurer is licensed in New York State. It is equal to zero otherwise. Larger insurers should be present in that state so we predict low reinsurance demand and a high liquidity creation ratio.

Cost of capital

Similar to Ayuso et al. (2004) and Jokipii and Milne (2008), we approximate this cost as the average return on equity (ROE) over the last five years, and predict a negative sign for that variable on reinsurance demand and a negative sign on liquidity creation.

Firm size

The natural logarithm of admitted assets is used as a proxy of firm size. Several studies predict that insurer size has a negative impact on demand for reinsurance. It should have a positive sign on liquidity creation. Small insurers may need more protection because it is more difficult for them to self-insure efficiently (Mayers and Smith, 1990; Hoyt and Khang, 2000; Garven and Lamm-Tennant, 2003; Weiss and Chung, 2004; Cole and McCullough, 2006). Large insurers should create more liquidity in the economy.

\section{Group affiliation}

We include a group dummy variable to indicate an affiliated insurer. The variable is equal to 1 if the insurer is affiliated to a group and 0 if it is non-affiliated. Mayers and Smith (1990) hypothesize that insurance companies that are members of a group are expected to reinsure within the group because this activity is profitable for the group and redistributes the group's overall taxes. Powell and Sommer (2007) find a significant positive effect for this assumption. We do not make any predictions about liquidity creation.

\section{Capital}

We propose a negative effect of capital on reinsurance demand since capital can be interpreted as a substitute for reinsurance. We do not introduce the capital variable in the liquidity creation equation because capital is used to compute the liquidity creation ratio.

Table 2 presents variable definitions and their symbols.

[Table 2 about here] 


\section{Basic model: OLS fixed effects model}

We first analyze the effect of liquidity creation on reinsurance demand and the effect of reinsurance demand on liquidity creation without introducing any modeling of causality between the two variables. One objective is to verify how our data and variables yield results that are comparable with the insurance literature. We use the following least-squares regression model with lagged variables for demand for reinsurance and liquidity creation where $y_{i, t}$ stands for reinsurance demand and $x_{i, t}$ for the liquidity ratio:

$$
\mathrm{y}_{i, t}=\beta_{y}+\beta_{1} \mathrm{x}_{i, t-1}+\beta_{2} \mathrm{y}_{i, t-1}+\delta_{1} \mathrm{w}_{i, t}+\alpha_{i}+\varepsilon_{i, t}
$$

and

$$
\mathrm{x}_{i, t}=\beta_{x}+\beta_{3} \mathrm{x}_{i, t-1}+\beta_{4} \mathrm{y}_{i, t-1}+\delta_{2} \mathrm{~s}_{i, t}+\eta_{i}+v_{i, t} .
$$

In equations (1) and (2), the liquidity creation ratio at time $t$ is regressed on the control variables at time $t$ and the reinsurance demand at time $t$ is regressed on control variables at $t$. As mentioned, our goal is to verify how the control variables perform to estimate the two dependent variables. We also want to verify the possible dependences between the two dependent variables. Both equations are estimated separately. Therefore, each equation of the model is in fact a dynamic panel data relationship with individual fixed effects $\left(\alpha_{i}, \eta_{i}\right)$ and vectors of covariates $\left(w_{i, t}, s_{i, t}\right)$ that may be non-exogenous. $\varepsilon_{i, t}$ and $v_{i, t}$ are error terms with zero mean and positive variance for $i=1 \ldots N$ and $t=1 \ldots T$, where $N$ is the number of firms and $T$ the number of periods. Insurers with more liquidity creation should be riskier and demand more reinsurance, while those with more reinsurance should be less risky and more active in liquidity creation. Yet these effects can vary for different firm sizes and time periods. There are less control variables in the liquidity creation regression because some variables described in Table 2 are ratios included in the definition of the liquidity creation ratio, as shown in Table 1.

The regressions are estimated with firm fixed effects. We also correct standard errors for within-firm correlation and heteroscedasticity using the Huber-White consistent estimator. This approach allows us to account for time-invariant unobservable firm characteristics and explore within-firm differences. 


\section{Descriptive statistics and preliminary results}

\subsection{Descriptive statistics}

Summary statistics for all insurers are shown in Table 3. To capture the variation in demand for reinsurance and liquidity creation by insurer size, we divide the sample of insurers into three classes:

1. Large insurers, whose total admitted assets are greater than $\$ 3$ billion;

2. Medium insurers, whose total admitted assets are between $\$ 1$ billion and $\$ 3$ billion;

3. Small insurers, whose total admitted assets are lower than $\$ 1$ billion.

Summary statistics for all variables are shown in Tables 3a, 3b and 3c in the appendix for large, medium and small insurers. Among the 34,376 insurer-year observations, large insurers consist of 1,336 observations, medium insurers represent 1,993 observations and small insurers account for 30,753 observations. The sum of the three groups is not equal to 34,376 because we need lagged observations for the estimations, and insurers may change their size category over time.

Table 3 indicates that the mean value of demand for reinsurance is $37.2 \%$, with a $28.1 \%$ standard deviation. Small insurers seem to use more reinsurance to mitigate risk. On average, demand for reinsurance for large insurers is $30.6 \%$, and it is $37.6 \%$ for small insurers, as Tables 3a and 3c show. Large insurers control 60\% of premium earned in the industry, and medium and small insurers control $18 \%$ and $22 \%$ of insurance activity respectively.

[Table 3 about here]

The average ratio of liquidity creation divided by total assets is -0.4295 , indicating that insurers generate liquidity de-creation normalized by total admitted assets, as Choi et al. (2013) demonstrate. The liquidity creation ratio is -0.4346 for small insurers, whereas for large and medium insurers the ratios are -0.3854 and -0.3886 respectively, indicating that large and medium insurers generate more liquidity in the economy than do small insurers. Large insurers control 65\% of liquidity de-creation, whereas medium and small insurers control 16\% and 19\% respectively.

The mean value of the insurance leverage ratio is 1.93 , and ranges from 0 to 33 . This ratio is, on average, 2.03 for small insurers, which is more than twice that of large insurers (0.77). According to Carson and Hoyt (1995), small insurers with higher levels of leverage are more likely 
to be associated with an increased probability of default than are large firms, whose leverage levels are lower on average.

The capital ratio variable also indicates variations among the different sizes of insurers. The capital ratio for large insurers is 0.37 and is 0.44 for small insurers. Therefore, small insurers have to maintain a higher level of capital than large insurers do, which affects liquidity creation because the surplus is assigned to illiquid liabilities.

Concentration variables by line, geographic area or business mix indicate that larger insurers are, on average, more diversified than medium and small insurers. Medium insurers are more diversified than small insurers.

Most large insurers are affiliated with a group (97\%), compared with $61 \%$ of small insurers. Small insurers bear more risk in relation to policyholders' surplus than large insurers; 3.0\% of small insurers have net premiums written to policyholders' surplus greater than $300 \%$, compared to $1.5 \%$ for large insurers. For large insurers, $33.2 \%$ have a liability to liquid assets ratio greater than $100 \%$, versus only $8.5 \%$ for small insurers and $17.7 \%$ for medium insurers.

The mean for the two-year loss development ratio is equal to $0.562 \%$ and $-3.106 \%$ for large insurers and small insurers respectively. On average, large firms have positive loss development, meaning that they are more likely to demand more reinsurance to mitigate potential financial constraints. The usual range for the two-year loss development ratio includes results below 20\%. Among the 34,376 observations, 7.35\% have values greater than $20 \%$, and $10.23 \%$ have values greater than $20 \%$ among large firms. Only $27.7 \%$ of small insurers held a New-York State license, compared with $81.2 \%$ for large insurers.

Figure 1 does not show a clear dependence between reinsurance demand and liquidity creation over the population of all insurers, while Figure 2 indicates that liquidity creation seems positively correlated with reinsurance demand for small insurers. For large insurers, reinsurance demand is rather constant over time which reduces a potential correlation between the two activities. The 2007-2009 financial crisis does not seem to have affected significantly the two trends. In fact we did not find any econometric significant effect of the crisis on the two dependent variables probably because insurers were not involved in structured finance (Kessler, 2014).The crisis has mainly damaged banks.

[Figures 1, 2, and 3 about here] 


\subsection{Preliminary econometric results}

Table 4 presents the results from the least-squares estimations and shows very important findings. For large, medium and small firms, the results are presented in tables $4 \mathrm{a}$, $4 \mathrm{~b}$ and $4 \mathrm{c}$ respectively in the appendix.

The results in Table 4 show a highly significant relationship between liquidity creation ratio and demand for reinsurance. An increase in liquidity creation ratio increases demand for reinsurance, as we predict. In addition, the coefficient is positively significant for small and medium insurers as shown in the appendix. It is not significant for large firms. The results in tables $4 \mathrm{~b}$ and $4 \mathrm{c}$ indicate that the impact of liquidity creation ratio on reinsurance demand is about the same for small insurers and medium insurers.

Demand for reinsurance positively affects the liquidity creation ratio only for small insurers, which seems to explain the overall result in Table 4 . These results in Table 4 will be investigated in more details in Sections 5 and 6, where causality will be considered. Section 7 contains a detailed analysis of the control variable results.

[Table 4 about here]

\section{Causality analysis based on Generalized Method of Moments}

In the previous section, we performed regressions to verify how reinsurance demand and liquidity creation can influence each other, but we did not implement any causality test. We could have used two-stage least squares estimations or simultaneous least squares estimations. However, we did not find appropriate exogenous instruments. Without valid instruments, the endogeneity problem cannot be solved with these estimation methods.

In this section, we first analyze the causality between reinsurance demand and liquidity creation by applying a robust Generalized Method of Moments (GMM) procedure to

estimate our parameters. More precisely, we use the regularized GMM procedure proposed by Carrasco and Nayihouba (2019) for panel data. An interesting property of the regularized GMM procedure is that there is no problem of convergence even if $T$ is large. In order words, this procedure could also be implemented if the time dimension of the panel data is moderately large, as in our application. Moreover, we do not need any distributional 
assumption. We are going to re-estimate equations (1) and (2) reported in (3) where again $y_{i, t}$ is for reinsurance demand and $x_{i, t}$ for the liquidity ratio:

$$
\left\{\begin{array}{l}
y_{i, t}=\beta_{1} x_{i, t-1}+\beta_{2} y_{i, t-1}+\delta_{1} w_{i, t}+\alpha_{i}+\varepsilon_{i, t} \\
x_{i, t}=\beta_{3} x_{i, t-1}+\beta_{4} y_{i, t-1}+\delta_{2} s_{i, t}+\eta_{i}+v_{i, t}
\end{array}\right.
$$

The estimation of (3) will also be done equation by equation. The presence of individual effects creates a correlation between the error term and the lagged value of the dependent variable, which is one of the explanatory variables. GMM method has been widely employed to estimate such models with lagged levels of the set of explanatory variables as instruments. An important feature of this model is the following: If a variable at a certain period of time can be used as an instrument, then all the past realizations of that variable can also be used as instruments. Therefore, the number of moment conditions can be very large even if the time duration of the panel $T$ is finite. In such models, we may face the problem of many instruments which involves a certain variance-bias trade-off, particularly in small sample estimation. Even though adding moment conditions leads to an efficiency gain according to the conventional asymptotic theory, in finite samples the bias can also increase with the number of instruments.

Several methods have been proposed in the context of cross-sectional data models to deal with this problem of instruments. For instance, Carrasco (2012) and Carrasco and Tchuente (2015) propose to solve this problem with several regularization procedures based on different ways to stabilize the inverse of the covariance matrix of instruments. To manage this problem in a dynamic setting, Okui (2009) recommends choosing the optimal number of moment conditions to minimize the mean square error of the estimation in order to improve the finite sample properties. However, the finite sample problem is not completely solved since there may be a large bias in estimated cross-lagged parameters when the auto-regressive coefficient in the dynamic panel is close to unity. Carrasco and Nayihouba (2019) propose a more general method based on different ways of inverting the covariance matrix of instruments. They show that this method improves the properties of the GMM estimation even if the auto-regressive coefficient is close to unity. To analyze the causality relationships in (3) we focus on two of the regularization procedures proposed by Carrasco and Nayihouba (2019) in the context of our dynamic panel data.

Let us first consider the standard GMM method. Without loss of generality, we assume that each component of (3) can be written as follows: 


$$
y_{i, t}=\theta z_{i, t}+\alpha_{i}+\varepsilon_{i, t}
$$

where $\theta=\left(\delta, \gamma^{\prime}\right)^{\prime}$ is the vector of parameters of interest with $\delta$ the auto-regressive coefficient in the dynamic panel associated with the lagged level of the dependent variable. $z_{i t}=\left(y_{i, t-1}, m_{i, t}^{\prime}\right)$ is the vector of explanatory variables including the lagged level of the dependent variable and other co-variates at $t$, which may be non-exogenous. Let $A$ denote the forward orthogonal deviation operator used in the study by Arellano and Bover (1995). $A$ is a matrix equal to $(T-1) \times T$. Multiplying the model by $A$, (4) becomes:

$$
y_{i, t}^{*}=\theta z_{i, t}^{*}+\varepsilon_{i, t}^{*}
$$

with

$$
E\left[Z_{i, t-s} \varepsilon_{i, t}^{*}\right]=0
$$

for $s=0, \ldots t-1$ and $t=1, \ldots T-1$, and where $s$ is for periods before $t$. We also have:

$$
z_{i}^{*}=A z_{i}, y_{i}^{*}=A y_{i} \text { and } \varepsilon_{i}^{*}=A \varepsilon_{i} .
$$

We will estimate $\theta$ by the standard GMM method based on the following set of moment conditions:

$$
E\left[Z_{i} \varepsilon_{i}^{*}\right]=0,
$$

for $i=1, \ldots, N$ with $\varepsilon_{i}^{*}=\left(\varepsilon_{i, 1}^{*}, \ldots \varepsilon_{i, T-1}^{*}\right)^{\prime}$. In a compact form, the standard GMM estimator of $\theta$ is given by:

$$
\hat{\theta}=\frac{\left(z^{*}\right)^{\prime} M y^{*}}{\left(z^{*}\right)^{\prime} M x^{*}}
$$

with

$$
M=Z\left(Z^{\prime} Z\right)^{-1} Z^{\prime}=\frac{Z}{\sqrt{N T}}\left(\frac{Z^{\prime} Z}{N T}\right)^{-1} \frac{Z^{\prime}}{\sqrt{N T}}=\frac{Z}{\sqrt{N T}} K_{N}^{-1} \frac{Z^{\prime}}{\sqrt{N T}},
$$

where $K_{N}=\frac{Z^{\prime} Z}{N T}$ is the sample covariance matrix of the orthogonality conditions, $Z=\left(Z_{1}^{\prime}, \ldots, Z_{N}^{\prime}\right)$ is a $N(T-1) \times \bar{q}$ block diagonal matrix, and $\bar{q}$ is the number of moment conditions in the estimation process $T \frac{T-1}{2}$. Blundell and Bond (1998) show that the lagged levels of the dependent variable, which appear in the explanatory variables, can 
become weak instruments when the auto-regressive parameter is close to unity. Moreover, according to Doran and Schmidt (2006), in applications with many instruments, the marginal contribution of some instruments can be small in the standard GMM framework. As a result, this GMM estimator may suffer from poor finite sample properties. Instead of estimating this standard GMM estimator, Carrasco and Nayihouba (2019) advocate computing the inverse of the sample covariance matrix of the orthogonality conditions $K_{N}$ to obtain a more stable estimator of $\theta$ that is robust to the presence of many instruments. Because the dimension of $K_{N}$ may be very large, some of the eigenvalues of this matrix can be too small such that the condition number, ${ }^{7}$ which determines the degree of illposedness in this estimation problem, can be large. According to Carrasco et al. (2007), to solve this problem, one can regularize the inversion of this sample covariance matrix by damping the explosive asymptotic effect of the inversion of the eigenvalues. More precisely, we replace the sequence $\left\{1 / \lambda_{j}\right\}$ of the explosive inverse eigenvalues $j$ by the following sequence of elements $\left\{q\left(\alpha, \lambda_{j}\right) / \lambda_{j}\right\}$ where the damping function $q(\alpha, \lambda)$ is chosen such that:

1. $q(\alpha, \lambda) / \lambda$ remains bounded when $\lambda \rightarrow 0$;

2. for any $\lambda, \lim _{\alpha \rightarrow 0} q(\alpha, \lambda)=1$,

where $\alpha$ is the regularization parameter and the damping function is specific to each regularization procedure (Judge et al., 1980; Kress, 1999).

In this paper, we focus on two forms of this damping function:

$$
q(\alpha, \lambda)= \begin{cases}\frac{\lambda}{\lambda+\alpha} & \text { for Tikhonov regularization, } \\ 1-(1-c \lambda)^{1 / \alpha} & \text { for Landweber-Fridman regularization. }\end{cases}
$$

By spectral decomposition, we have that

$$
K_{N}=P_{N} D_{N} P_{N}^{\prime}
$$

with $P_{N}^{\prime} P_{N}=I_{\bar{q}}$, where $P_{N}$ is the matrix of eigenvectors and $D_{N}$ the diagonal matrix with eigenvalues $\lambda_{j}$ on the diagonal. Let $K_{N}^{\alpha}$ denote the regularized inverse of $K_{N}$ given by:

\footnotetext{
${ }^{7}$ The condition number is given by $\lambda \max / \lambda \min$ with $\lambda \max$ being the largest eigenvalue and $\lambda \min$ the smallest eigenvalue of $K_{N}$.
} 


$$
K_{N}^{\alpha}=P_{N} D_{N}^{\alpha} P_{N}^{\prime}
$$

where $D_{N}^{\alpha}$ is the diagonal matrix with elements $q\left(\alpha, \lambda_{j}\right) / \lambda_{j}$. From the regularized inverse $K_{N}^{\alpha}$ of $K_{N}$ one obtains that

$$
M^{\alpha}=\frac{Z}{\sqrt{N T}} K_{N}^{\alpha} \frac{Z^{\prime}}{\sqrt{N T}} .
$$

Therefore, the regularized GMM estimator of $\theta$ is given by

$$
\hat{\theta}^{\alpha}=\frac{\left(z^{*}\right)^{\prime} M^{\alpha} y^{*}}{\left(z^{*}\right)^{\prime} M^{\alpha} x^{*}}
$$

Carrasco and Nayihouba (2019) derive the asymptotic properties of this estimator with the same assumptions as in Okui (2009). In particular, the consistency and the asymptotic normality properties of the model are derived. Moreover, they propose a data-driven procedure based on the Mean Square Error approximation in order to select the regularization parameter in an optimal way.

When the number of moment conditions exceeds the number of unknown parameters to be estimated by GMM, the model validity must be verified by testing the over-identifying restriction before making any inferences in the resulting estimation. A common test for this purpose is the Jtest as proposed by Sargan (1958) and Hansen (1982). To test if our models are well specified, we apply the modified version of the J-test proposed by Arellano and Bond (1991) in the context of dynamic panel data models.

The results of our estimations are given in Table 5. Robust standard errors are used for obtaining confidence intervals. Quantities in brackets are the associated $p$-values for each coefficient. We observe that the standard GMM estimation is rejected by the J-test in our estimations where the number of periods is quite large. We also observe that the cross-effect between reinsurance demand and liquidity ratio are under-evaluated in each equation with the standard GMM model when compared with the two other regularized methods, which confirms the potential bias for the estimators obtained from the standard GMM methodology. When we compare the results of Table 4 with those of the two regularized models in Table 5, the significance and sign of most of the other coefficients are not affected, with the exceptions of tax exemption and loss development in the reinsurance demand equation and information asymmetry in the liquidity ratio equation. Moreover, the cross effects coefficients between liquidity creation and 
demand for reinsurance in Table 4 are closer to those in the two regularized estimation methods than those in the standard GMM estimation.

We still observe that the standard GMM model is rejected in Tables 5a, 5b, and 5c. Results in Table 5c confirm those of Table 5 for small insurers and show that the cross-effects are again under-evaluated by the standard GMM model for the effect of reinsurance demand on liquidity creation. Results in Table 5a do not show a significant relationship between liquidity creation and reinsurance demand for large firms which seems to confirm the results in Table 4a, that the two activities as independent for these insurers For medium insurers, results in Table 5b indicate that liquidity creation increases the demand for reinsurance with, again, a lower coefficient for the standard GMM model. But the converse is not verified for the three estimations as it was in Table 4b. In conclusion, the results from the regularized GMM estimations establish a bi-causal relationship between liquidity creation and demand for reinsurance for small insurers and all insurers together.

[Table 5 about here]

\section{Causality analysis based on Maximum Likelihood method}

The regularized GMM estimation procedure shows that the causal relationship between reinsurance demand and liquidity creation is bidirectional for small insurers and all insurers, that is, the liquidity creation ratio has a positive effect on reinsurance demand, and the reciprocal causal effect is also observed. As a robustness test, we apply another estimation procedure to confirm this important result. The Maximum Likelihood (ML) model can also estimate reciprocal causal effects between two variables. Consider the following set of equations:

$$
\begin{aligned}
& \mathrm{y}_{i t}=\mu_{t}+\beta_{1} \mathrm{x}_{i, t-1}+\beta_{2} y_{i, t-1}+\delta_{1} w_{i t}+\alpha_{i}+\varepsilon_{i t} \\
& x_{i t}=\tau_{t}+\beta_{3} \mathrm{x}_{i, t-1}+\beta_{4} y_{i, t-1}+\delta_{2} s_{i t}+\eta_{i}+v_{i t}
\end{aligned}, t=2, \cdots, T
$$

where $\mu_{t}$ and $\tau_{t}$ are intercepts that vary with time, $\beta_{1}, \beta_{2}, \beta_{3}$ and $\beta_{4}$ are scalar coefficients, and $\varepsilon_{i, t}$ and $v_{i, t}$ are random disturbances.

As previously, equation (12) contains fixed effects terms $\alpha_{i}$ and $\eta_{i}$, which vary across firms. It also contains vectors of control variables $w_{i t}, s_{i t}$, as in (3), that vary over both firms and 
time. Their corresponding vectors of coefficients are $\delta_{1}$ and $\delta_{2}$. When the model is having trouble converging, we standardize the control variables.

The coefficients for stability and lagged cross-effects are, respectively, constrained to equality across waves, making these parameters equivalent to average effects over the duration of the panel. We use the Maximum Likelihood of Structural Equation Modeling (ML-SEM) to estimate the parameters in (12). This method tends to work best when panels are strongly balanced, $T$ is not too large, and there are no missing values. Only $16 \%$ of the firms studied (i.e. 489) are observed each year over all 23 years. To keep more observations while applying these conditions to our data set we also separated our data into three periods: 1992-1999 (8 years); 2000-2007 (8 years); and 2008-2014 (7 years). From 1992 to 1999, we observe, in Table 3d of the appendix, that there are 1,072 firms present for all 8 years. There are 1,063 firms in 2000-2007 that are observed in all 8 years and 1,108 firms observed in all 7 available years from 2008 to 2014.

Unfortunately, attempting to combine a fixed effects model with a cross-lagged model leads to serious estimation problems with the ML-SEM approach. The estimation difficulties include error terms that are correlated with predictors, the so-called incidental parameters problem. Therefore, equations in (12) cannot be estimated simultaneously for causality analysis. The fixed effects in each equation must be modeled as a latent variable that is allowed to be correlated with all time-varying predictor variables. The rationale for the method is described in the works of Teachman et al. (2001) and Allison and Bollen (1997). The assumption of sequential endogeneity is modeled by allowing the error term at each point in time to be correlated with the future values of the time-dependent covariates, but not with past values (Woolridge, 2002).

ML-SEM assumes multivariate normality for all endogenous variables while GMM makes no distributional assumptions. However, ML-SEM produces consistent estimators even when the normality assumption is violated (Moral-Benito, 2013; Allison et al., 2017). In this case, robust standard errors can be computed for obtaining confidence intervals and hypothesis tests. We use robust standard errors in all tables of results to obtain the corresponding $p$-values.

Maximum Likelihood estimations of Structural Equation Modeling (ML-SEM) sometimes fail to converge. We therefore include in the model only the variables that improve the fit. A wide array of fit indices was developed (Schermelleh-Engel et al. 2003; Ding et al., 1995; Sugawara and MacCallum, 1993): Root Mean Square Error of Approximation; Comparative Fit Index; 
Tucker-Lewis Index; and Standardized Root Mean Square Residual. These indices and their critical values are described in the appendix.

The strict exogeneity in the linear panel model for $y_{i t}$ with fixed effects can be established by verifying that $E\left(\varepsilon_{i t} \mid \mathrm{w}_{i}, \alpha_{i}\right)=0$; (Wooldrige, 2010). An equivalent condition exists for $x_{i t}$. A test of strict exogeneity using fixed effects, when $\mathrm{T}>2$, is obtained by estimating equation (13):

$$
\mathrm{y}_{i t}=\delta_{1} w_{i t}+\phi_{1} z_{i t+1}+\alpha_{i}+\varepsilon_{i t}, \quad t=1,2, \cdots, T-1
$$

where $w_{i t}$ is a vector of predetermined variables and $z_{i t+1}$ is a vector of exogenous variables. An equivalent equation can be estimated for $x_{i t}$. A test for strict exogeneity for each variable in each equation can be written as, $H_{0}: \phi_{j k}=0$, where $j=1,2$ is for reinsurance demand and liquidity creation respectively and $k=1,2 \ldots K$ is for variable $k$. Table 6 presents $p$-values for the test $H_{0}: \phi_{j k}=0$. We consider a variable as strictly exogenous when the $p$-value is greater than 0.10 . Otherwise, the independent variables will be considered predetermined variables.

\section{[Table 6 about here]}

We observe in Table 6 that reinsurance price, tax exemption and capital are strictly exogenous variables for the estimation of reinsurance demand and that regulatory pressure, tax exemption, and cost of capital are strictly exogenous for the estimation of the liquidity ratio variable. All other variables are considered as predetermined variables in the two equations ( $p$ value $<0.10$ ) for all periods.

Table 7 presents the estimation results with control variables included in the model following the selection results in Table 6. From Table 7 we observe that the cross-effects between reinsurance demand and liquidity ratio are significant with parameters similar to those obtained with the regularized GMM estimations in Table 5. These findings support the causal reciprocal effects model in which each variable exerts a causal influence on the other over time. The coefficients of the control variables are not significantly affected when compared with previous estimations, exept for reinsurance price, tax exemption and information asymmetry. However, these differences can be explained by different model specifications and data, as we will see later.

[Tables 7 and 8 about here]

To confirm our results, in Table 8 we re-estimate the GMM model with the same specification and number of observations as in Table 7. The results in Table 7 seem to confirm that the ML-SEM model is another way to overcome the standard GMM estimation problems (Moral- 
Benito, 2013). We observe that the ML-SEM results in Table 7 yield very similar results as the regularized GMM method in Table 8. The same control variables are significant and the standard GMM is still rejected and continues to under-evaluate the cross-effects between reinsurance demand and liquidity creation, but to a lower extend. This can be explained by the use of less control variables and observations in Table 8 than in Table 5.

We now focus on the coefficient estimates of $\beta_{1}$, the cross lagged effect of liquidity creation on reinsurance demand and $\beta_{4}$, the cross lagged effect of reinsurance demand on liquidity creation. The coefficient estimates of $\beta_{1}$ varies from 0.04 (standard GMM, Table 8) to 0.0804 (Tikhonov regularized GMM, Table 8), 0.0797 (Landweber-Fridman regularized GMM, Table 8), and 0.0846 (ML-SEM, Table 7). The coefficient estimates of $\beta_{4}$ varies from 0.04 (standard GMM, Table 8) to 0.0490 (Tikhonov regularized GMM, Table 8), 0.0655 (LandweberFridman regularized GMM, Table 8), and 0.0590 (ML-SEM, Table 7). This confirms ( with few exceptions) the lower estimates of the standard GMM method compared with the other estimation methods.

We obtain similar results over the entire period for small insurers. The conclusions remain about the same as those obtained from Tables 7 and 8, respectively. Results are available upon request. As shown in tables 9a to 9d in the appendix, the results do not differ significantly with more observations and shorter periods for both estimation methods. The results in Table 9b still show that the standard GMM is rejected and under-estimates the effects of liquidity creation on reinsurance demand when compared with regularized estimations in Tables 9c and 9d, and with the ML-SEM results in Table 9a.

\section{Detailed analysis of the control variable results}

We now compare the main results for the control variables obtained from the OLS estimations with those of the GMM estimations in Tables 4 and 5. They are summarized in Tables 10 to 13 in the appendix for all observations and different insurer sizes (a, b, c). We observe that the estimation results are stable between different estimation methods. We do not discuss the MLSEM results with less observations and different specifications but we have already shown that the results in Tables 7, and 8 are very similar even for the control variables when comparing the 
regularized GMM estimations with the ML-SEM estimations having the same specification and number of observations.

Insurance leverage ratio

The coefficient of the insurance leverage ratio is positively and significantly related to demand for reinsurance, suggesting that firms that write more business relative to surplus have a greater need for reinsurance because they have a higher probability of insolvency. This is a standard result found in the risk management literature (Dionne, 2019). This result is robust whatever the size of the insurer and the estimation method. The variable is not present in the liquidity ratio estimation because it was used for the definition of the dependent variable.

Line of business, geographic and business mix concentration

As discussed previously the prediction for the signs of these coefficients is quite uncertain, and the results are rather mixed. Both line of business and geographic concentration are negative or not significantly related to reinsurance demand and liquidity creation. Business mix concentration is almost nonsignificant in both equations with all estimation methods and firm sizes.

Regulatory pressure

Regulatory pressure is significantly and negatively related to demand for reinsurance and positively related to the liquidity creation ratio for all insurers and small insurers. Accordingly, firms whose net premiums to surplus ratio is higher than $300 \%$ demand less reinsurance and are more active in liquidity creation, as predicted.

\section{Liabilities to liquid asset ratio}

Firms whose liabilities exceed their liquid assets are expected to purchase more reinsurance. We find this result for small insurers and all insurers with the exception of the standard GMM model. This variable was not used in the liquidity creation equation.

\section{Reinsurance price}

The reinsurance price measured by the inverse of the economic loss ratio is significantly and negatively related to reinsurance demand, and significantly and positively related to the liquidity creation ratio for all insurers and small insurers (same results sometimes for medium insurers). For large insurers, this price is significantly and negatively related to the demand for 
reinsurance (with the exception of standard GMM) and not significantly related to the liquidity creation ratio.

Tax exemption

Garven and Lamm-Tennant (2003) suggest that, since reinsurance can reduce the effects of large unexpected losses, it increases the probability that an insurer would gain some benefit from investment in tax-favored asset. In examining the effect of tax-exemption income relative to total investment income on demand for reinsurance and on the liquidity creation ratio, we find insignificant results except for all insurers with a significant positive relationship for reinsurance demand ( with the exeption of the OLS model) and, for all insurers and small insurers, a significant negative relationship for liquidity creation, indicating that insurers who invest more in tax-favored assets purchase more reinsurance but they create less liquidity in the economy.

Information asymmetry

Information asymmetry is not significantly related ( at $5 \%$ ) to the liquidity creation ratio for all and small insurers. It affects the demand for reinsurance positively for the same insurers and affects positively liquidity creation for large insurers. It is never significant for medium insurers.

Two-year loss development

We use the two-year loss development variable to determine if variation of loss reserves affects the demand for reinsurance and the liquidity creation ratio. The variable is not significant with the exception of a positive effect for reinsurance demand by all insurers. Loss development is not significant for liquidity creation.

New York license

Insurers that have a license in New York State purchase more reinsurance and are not significantly related to the liquidity creation ratio. We find the same results among all insurers, small and medium insurers. For large insurers, we also find no relationship with liquidity creation ratio but a significant and negative relationship with demand for reinsurance.

Cost of capital

The coefficient of cost of capital is negatively and significantly related to demand for reinsurance and is also negatively and significantly related to the liquidity creation ratio for small insurers and all insurers.It is not significant for large and medium insurers. 


\section{Firm size}

We find a negative relationship between firm size and insurers’ reinsurance demand for all and small insurers implying that, when firm size decreases, insurers are more likely to purchase reinsurance as a way to manage unexpected losses (Mayers and Smith, 1990). The firm size variable is positively and significantly related to the liquidity creation ratio for all, small and medium insurers. So smaller insurers in terms of the logarithm of total admitted assets are more likely to purchase reinsurance and less likely to create liquidity.

\section{Group affiliation}

The firm affiliation variable is positive for the demand for reinsurance for small and all insurers, indicating that insurers affiliated with a group demand more reinsurance. This variable is not significantly related to the liquidity creation ratio, except for medium firms affiliated with a group, which tend to create more liquidity.

\section{Capital}

The demand for reinsurance is significant and positively associated with capital. This surprising result does not vary according to different sizes of insurers and methods of estimation. The variable was not used in the liquidity ratio estimation.

\section{Conclusion}

This study analyzes how liquidity creation and demand for reinsurance are related, a relationship that has not been studied adequately in the literature because causality between the two activities has not been taken into account formally. Our statistical analysis indicates that liquidity creation has a positive causal effect on reinsurance demand for most insurers, meaning that those that take a more active position in risky investments buy more reinsurance protection. Only larger reinsurers that create more liquidity are not likely to purchase more reinsurance. In fact, their reinsurance demand is rather constant during our period of analysis, while liquidity creation was more volatile. Conversely small insurers that buy more reinsurance create more liquidity in the economy. Because they feel more protected, they become more active in riskier investments with higher maturity.

We performed a causality analysis by applying two complementary methodologies that yield comparable results with same econometric specifications and same data. One important result 
from our analysis is that we reject the standard GMM method in all estimations. We also show that the standard GMM underestimates the cross-effects between liquidity creation and reinsurance demand when the period of estimation is relatively large or when the auto-regressive parameters of the two dependent variables, i.e. reinsurance demand or liquidity creation, are important. These results justify the use of more sophisticated methods of estimation that regularize the estimation procedure by including ways to stabilize the inverse of the covariance matrix of instruments with panel data (Carrasco and Nayihouba, 2019). For robustness we also estimated the ML-SEM model and obtained very similar econometric results to those of the two regularized GMM methods in comparable environments.

Many extensions to our research are possible. A first important one would be to apply our methodologies to the relationship between liquidity creation and bank capital to test for bidirectional causality. Another extension would be to estimate the two equations in the model simultaneously.

Finally, we could consider the roles of insurers' risk management and financial intermediary activities as complements or substitutes to liquidity creation and demand for reinsurance. Insurers as financial intermediaries obtain money from their policyholders in the form of premium payments and invest the funds raised in financial assets which is related to liquidity creation but not identical. Another important economic function of property-liability insurers is to provide risk pooling (diversification) and risk bearing services to their policyholders, and these services are a primary driver of the need for risk management a complement activity to reinsurance demand. Cummins et al. (2009) show that risk management and financial intermediation improve insurer financial performance. But they did not consider liquidity creation nor reinsurance demand activities. 


\section{References}

Adams, M., Hardwick, P., and Zou, H., 2008. Reinsurance and corporate taxation in the United Kingdom life insurance industry. Journal of Banking and Finance 32, 101-115.

Alhassan, A.L., Biekpe, N., 2019. Why do property-liability insurers destroy liquidity? Evidence from South Africa. South African Journal of Economics 87, 1, 22-45.

Allison, P. and Bollen, K.A., 1997. Change score, fixed effects, and random component models: A structural equation approach. Paper presented in the Annual Meeting of the American Sociological Association.

Allison, P.D., Williams, R., and Moral-Benito, E., 2017. Maximum likelihood for crosslagged panel models with fixed effects. Socius: Sociological Research for a Dynamic World 3, 117.

Arellano, M. and Bond, S., 1991. Some tests of specification for panel data: Monte Carlo evidence and an application to employment equations. The Review of Economic Studies 58(2), 277-297.

Arellano, M. and Bover, O., 1995. Another look at the instrumental variable estimation of errorcomponents models. Journal of Econometrics 68, 29-51.

Ayuso, J., Perez, D., and Saurina, J., 2004. Are capital buffers pro-cyclical? Evidence from Spanish panel data. Journal of Financial Intermediation 13, 259-264.

Bai, J., Krishnamurthy, A., and Weymuller, C.H., 2018. Measuring liquidity mismatch in the banking sector. The Journal of Finance 73(1), 51-93.

Berger, A. N., and Bouwman C.H.S., 2009. Bank liquidity creation. The Review of Financial Studies 22(9), 3779-3837.

Blundell, R. and Bond, S., 1998. Initial conditions and moment restrictions in dynamic panel data models. Journal of Econometrics 87, 115-143.

Bouwman, C.H.S., 2014. Liquidity: How banks create it and how it should be regulated? In: Berger, N., Molyneux, P., and Wilson, J.O. (Eds), The Oxford Handbook Banking ( $2^{\mathrm{d}}$ Edition), Oxford University Press, NY, USA.

Browne, M.W. and Cudeck, R., 1993. Alternative ways of assessing model fit. In: Bollen, K.A. and Long, J.S. (Eds.), Testing Structural Equation Models (pp. 136-162). Newbury Park, CA: Sage.

Bryant, J., 1980. A model of reserves, bank runs, and deposit insurance. Journal of Banking and Finance 4, 335-344.

Carrasco, M. and Nayihouba, A., 2019. A regularization approach to the dynamic panel data model estimation. Mimeo, University of Montreal.

Carrasco, M. and Tchuente, G., 2015. Regularized LIML for many instruments. Journal of Econometrics 186, 427-442. 
Carrasco, M., 2012. A regularization approach to the many instruments problem. Journal of Econometrics 170, 383-398.

Carrasco, M., Florens, J.P. and Renault, E., 2007. Linear inverse problems in structural econometrics estimation based on spectral decomposition and regularization. Handbookof Econometrics 6, 5633-5751.

Carson, J.M., and Hoyt, R.E., 1995. Life insurer financial distress: classification models and empirical evidence. Journal of Risk and Insurance 6(2), 764-775.

Chang, V.Y., 2015, Determinants of the demand for reinsurance for the US property-liability insurance industry: quantile regression analysis. Management Review 24, 125-138.

Chang, V.Y., Jeng, V.S. and Tzeng, L.Y., 2103. The relationship among the demand for reinsurance, liquidity and leverage in the U.S. property-liability insurance industry. Working Paper.

Chen, F.F. (2007). Sensitivity of goodness of fit indexes to lack of measurement invariance. Structural Equation Modeling: A Multidisciplinary Journal 14(3), 464-504.

Choi, B.P., Park, J., and Ho, C.L., 2013. Liquidity creation or de-creation evidence from US property and liability insurance industry. Managerial Finance 39(10), 938-962.

Christensen, T.E., Hoyt, R. E and Paterson, J.S., 1999. Ex ante investigation of the performance of the U.S. property-liability insurance industry. Journal of Business Finance and Accounting 64, 371-381.

Cole, C.R., and McCullough, K.A., 2006. A reexamination of the corporate demand for reinsurance. The Journal of Risk and Insurance 73(1), 169-192.

Cummins, J.D., Dionne, G., Gagné, R., and Nouira, A., 2008. The costs and benefits of reinsurance. Working Paper 08-01, Canada Research Chair in Risk Management, HEC Montréal.

Cummins, D., Dionne, G., Gagné, R., and Nouira, A., 2009. Efficiency of insurance firms with endogenous risk management and financial intermediation activities. Journal of Productivity Analysis 32(2), 145-159.

Cummins, J.D., and Nini, G.P., 2002. Optimal capital utilization by financial firms: evidence from the property-liability insurance industry. Journal of Financial Services Research 21, $15-53$.

Diamond, D.W., and Dybvig, P.H., 1983. Bank runs, deposit insurance and liquidity. Journal of Political Economy 91, 401-419.

Ding, L., Velice, W.F., and Harlow, L.L., 1995. The effects of estimation methods, number of indicators per factor and improper solutions on structural equation modeling fit indices. Structural Equation Modeling 2, 119-144.

Dionne, G., 2019. Corporate Risk Management: Theories and Applications, John Wiley and Sons, $384 \mathrm{p}$. 
Dionne G., and Triki, T., 2013. On risk management determinants: What really matters? Europ. J. Finance 19(2), 145-164.

Doran, H.E. and Schmidt, P., 2006. GMM estimators with improved finite sample properties using principal components of the weighting matrix, with an application to the dynamic panel data model. Journal of Econometrics 133, 387-409.

Garven, J.R., and Lamm-Tennant, J., 2003. The demand for reinsurance: Theory and empirical tests. Insurance and Risk Management 7(3), 217-237.

Gaver J.J., and Paterson, J.S., 1999. Managing insurance company financial statements to meet regulatory and tax reporting goals. Contemporary Accounting Research 16, 207-241.

Grace, E.V., 1990. Property-liability insurer reserve errors: A theoretical and empirical analysis. Journal of Risk and Insurance 57, 28-46.

Graham, J.R., and Rogers, D.A., 2002. Do firms hedge in response to tax incentives? Journal of Finance 57, 815-839.

Grubisic, E., and Leadbetter, D., 2007. The determinants of capital in the PandC insurance industry. Working Paper, ARIA Annual Meeting, Quebec City.

Hansen, L.P., 1982. Large sample properties of generalized method of moments estimators. Econometrica 50(4) 1029-1054.

Harrington, S.E., and Danzon, P.M., 1994. Price cutting in liability insurance markets. The Journal of Business 67(4), 511-538.

Holmstrom, B. and Tirole, J., 1998. Public and private supply of liquidity. Journal of Political Economy 106 1-40.

Horváth, R., Seidler, J., and Weill, L., 2012. Bank capital and liquidity creation: Granger causality evidence. IOS Working Papers no 318. Institut für Ostund, Südosteuropaforschung (IOS), Regensburg. http://nbn-resolving.de/urn:nbn:de:101:1-201207106474.

Hoyt, R. and Khang, H., 2000. On the demand of corporate property insurance. The Journal of Risk and Insurance 67(1), 91-1007.

Hu, L.T. and Bentler, P.M., 1999. Cutoff criteria for fit indexes in covariance structure analysis: Conventional criteria versus new alternatives. Structural Equation Modeling: A Multidisciplinary Journal 6(1), 1-55.

Hu, L.T. and Bentler, P.M., 1998. Fit indices in covariance structure modeling: Sensitivity to under parameterized model misspecification. Psychological Methods 3(4), 424-453.

Jean-Baptiste, E.L., and Santomero, A.M., 2000. The design of private reinsurance contracts. Journal of Financial Intermediation 9(3), 274-297.

Kessler, D., 2014. Why (Re)insurance is not systemic. Journal of Risk and Insurance 81(3), 477488. 
Khang, T., and Milne, A., 2008. The cyclical behavior of European Bank capital buffers. Journal of Banking and Finance 32(8), 1440-1451.

Judge, G., Griffiths, W., Hill, R.C., Lutkepohl, H., and Lee, T.C., 1980. The Theory and Practice of Econometrics, John Wiley and Sons, New York.

Kashyap, A.K., Rajan, R.G., and Stein, C.C., 2002. Banks as liquidity providers: An explanation for the coexistence of lending and deposit-taking. Journal of Finance 57, 33-73.

Kim, W.J., Mayers, D., and Smith, C.W., 1996. On the choice of insurance distribution systems. Journal of Risk and Insurance 63, 207-227.

Kress, R., 1999. Linear Integral Equations. Springer, Applied Mathematical Sciences, New York.

Liu, H.H., Shiu, Y.M. and Liu, T.C., 2016. Reinsurance and liquidity: Evidence from the United Kingdom general insurance industry. The Geneva Papers 41, 307-324.

Mayers, D., and Smith, C.W. Jr., 1982. On the corporate demand for insurance. The Journal of Business 55(2), 140-144.

Mayers, D., and Smith, C.W. Jr., 1990. On the corporate demand for insurance: Evidence from the reinsurance market. The Journal of Business 63(1), Part 1, 19-40.

Moral-Benito, E., 2013. Likelihood-based estimation of dynamic panels with predetermined regressors. Journal of Business \& Economic Statistics 31, 451-472.

NAIC, 2014, Insurance Regulatory Information System (IRIS) Ratios Manual.

Okui, R., 2009. The optimal choice of moments in dynamic panel data models. Journal of Econometrics 151, 1-16.

Petroni, K.R., 1992. Optimistic reporting in the property-casualty insurance industry. Journal of Accounting and Economics 15, 485-508.

Powell, L.S., and D.W. Sommer, 2007, Internal versus external capital markets in the insurance industry: The role of reinsurance, Journal of Financial Services Research 31(3), 173-188.

Sargan, J.D., 1958. The estimation of economic relationships using instrumental variables. Econometrica: Journal of the Econometric Society, 393-415.

Schermelleh-Engel K., Moosbrugge H., and Müller H., 2003. Evaluating the fit of structural equation models: Tests of significance and descriptive goodness-of fit measures. Methods of Psychological Research Online 8(2), 23-74.

Scordis, N.A., and Steinorth, P., 2012. Value from hedging risk with reinsurance. Journal of Insurance Issues 35(2), 210-231.

Shiu, Y.M., 2011. Reinsurance and capital structure: Evidence from the United Kingdom nonlife insurance industry. Journal of Risk and Insurance 78, 475-494. 
Shortridge, R.T., and Avila, S.A., 2004. The impact of institutional ownership on the reinsurance decision, Risk Management and Insurance Review 7(2), 93-106.

Sommer, D.W, 1996. The impact of firm risk on property-liability insurance prices. Journal Risk of Insurance 63(3), 501-514.

Sugawara, H.M. and McCallum, R.C., 1993. Effect of equation method on incremental fit indices for covariance structure models. Applied Psychological Measurement 17, 365-377.

Teachman, J and., Duncan, G.J., Yeung W.J., and Levy D., 2001. Covariance structure models for fixed random effects. Sociological Methods and Research 30, 271-288.

Wang, J. L., Chang, V.Y., Lai, G.C., and Tzeng, L.Y., 2008. Demutualization and demand for reinsurance. The Geneva Papers on Risk and Insurance - Issues and Practice 33, 566-584.

Weiss, M.A., and Chung, J.-H., 2004. U.S. reinsurance prices, financial quality, and global capacity. The Journal of Risk and Insurance 71(3), 437-467.

Winter, R.A., 1994. The Dynamics of competitive insurance markets. Journal of Financial Intermediation 3, 379-415.

Wooldridge, J., 2002. Econometric Analysis of Cross Section and Panel Data. Cambridge, MA: MIT Press. 


\section{Table 1: Liquidity creation measure for an insurer}

Step 1: We classify all items in assets, liabilities and surplus as liquid or illiquid.

Step 2: Assign weights to the activities

Step 3: Combine insurance activities as classified in step 1 and as weighted in step 2 to construct the liquidity creation (LC) measure

$$
\begin{aligned}
& \text { LC }=+1 / 2 \times \text { illiquid assets } \quad-1 / 2 \times \text { liquid assets } \\
& +1 / 2 \times \text { liquid liabilities } \quad-1 / 2 \times \text { illiquid liabilities } \\
& -1 / 2 \times \text { surplus }
\end{aligned}
$$

\begin{tabular}{|c|c|}
\hline \multicolumn{2}{|c|}{ Assets } \\
\hline Illiquid assets (weight = 1/2) & Liquid assets (weight $=-1 / 2$ ) \\
\hline Mortgage loan & $\begin{array}{l}\text { Cash, cash equivalents and short-term } \\
\text { investments }\end{array}$ \\
\hline Real estate & Investments in stock and bonds \\
\hline \multicolumn{2}{|l|}{ Other invested assets } \\
\hline \multicolumn{2}{|c|}{ Uncollected premiums and agents' balances } \\
\hline \multicolumn{2}{|c|}{$\begin{array}{l}\text { Electronic data processing equipment and } \\
\text { software }\end{array}$} \\
\hline Furniture and equipment & \\
\hline
\end{tabular}

\begin{tabular}{|c|c|}
\hline Liquid liabilities $($ weight $=1 / 2$ ) & Illiquid liabilities plus surplus (weight $=-1 / 2$ ) \\
\hline $\begin{array}{l}\text { Loss reserves within one year (Net losses and } \\
\text { expenses unpaid) }\end{array}$ & Loss reserves with more than one year \\
\hline $\begin{array}{l}\text { Reinsurance payable on paid losses and loss } \\
\text { adjustment expenses }\end{array}$ & $\begin{array}{l}\text { Funds held by company under reinsurance } \\
\text { treaties }\end{array}$ \\
\hline Other expenses & Provision for reinsurance \\
\hline Taxes, licenses and fees & $\begin{array}{l}\text { Amounts withheld or retained by company } \\
\text { on others' behalf }\end{array}$ \\
\hline Current federal and foreign income taxes & Draft outstanding \\
\hline Net deferred tax liability & $\begin{array}{l}\text { Liability for amounts held under } \\
\text { uninsured accident and health plans }\end{array}$ \\
\hline Unearned premiums & Surplus \\
\hline Dividends declared unpaid & \\
\hline
\end{tabular}

\section{Liabilities plus surplus}


Table 2: Independent variable: definition and construction

\begin{tabular}{|c|c|c|}
\hline Variable name & Symbol & Variable definition and construction \\
\hline $\begin{array}{l}\text { Insurance leverage } \\
\text { ratio }\end{array}$ & Insurance leverage & Direct business written to surplus \\
\hline $\begin{array}{l}\text { Geographical } \\
\text { concentration in direct } \\
\text { premiums written }\end{array}$ & $\begin{array}{l}\text { Geographical } \\
\text { concentration }\end{array}$ & $\begin{array}{l}\text { Herfindahl index defined as } \sum_{l=1}^{55}\left(\frac{P W_{l}}{T P W}\right)^{2} \text { where } \mathrm{PW}_{\mathrm{l}} \text { is the value of } \\
\text { direct premium written in each state and TPW represent the } \\
\text { insurer's total direct premiums written }\end{array}$ \\
\hline $\begin{array}{l}\text { Line of business } \\
\text { concentration in direct } \\
\text { premium written }\end{array}$ & Line concentration & $\begin{array}{l}\text { Herfindahl index defined as } \sum_{l=1}^{22}\left(\frac{P W_{l}}{T P W}\right)^{2} \text { where } \mathrm{PW}_{\mathrm{l}} \text { is the value } \\
\text { of direct premiums written in each line of business in the insurers' } \\
\text { annual statement and TPW represents the insurer's total direct } \\
\text { premiums written }\end{array}$ \\
\hline $\begin{array}{l}\text { Business mix } \\
\text { concentration }\end{array}$ & Mix concentration & $\begin{array}{l}\text { Herfindahl index of short and long tails or personal and } \\
\text { commercial lines }\end{array}$ \\
\hline Regulatory pressure & Regulatory pressure & $\begin{array}{l}\text { Dummy variable equal to } 1 \text { if firm's net premium to surplus ratio } \\
\geq 300 \text { percent, } 0 \text { otherwise }\end{array}$ \\
\hline $\begin{array}{l}\text { Liabilities to liquid } \\
\text { asset ratio }\end{array}$ & Liabilities & $\begin{array}{l}\text { Dummy variable equal to } 1 \text { if firm's adjusted liabilities to liquid } \\
\text { assets ratio } \geq 100 \text { percent, } 0 \text { otherwise }\end{array}$ \\
\hline Reinsurance price & Reinsurance price & $\begin{array}{l}\frac{\text { Netpremium written - exp }- \text { divp }}{D \times \text { losses incurred }} \\
\text { where exp = Commissions, expenses paid and aggregate write-ins } \\
\text { for deduction; } \\
\text { divp = Dividend paid } \\
D \text { is the Discount factor used in Winter (1994) to calculate the } \\
\text { economic loss ratio. } \\
\text { Losses incurred is losses incurred in current year. }\end{array}$ \\
\hline $\begin{array}{l}\text { Tax exemption } \\
\text { investment income }\end{array}$ & Tax exemption & $\begin{array}{l}\text { Bond interest exempt from federal taxes plus } 70 \% \text { of dividends } \\
\text { received from common and preferred stock to total investment }\end{array}$ \\
\hline $\begin{array}{l}\text { Information } \\
\text { asymmetry }\end{array}$ & $\begin{array}{l}\text { Information } \\
\text { asymmetry }\end{array}$ & Standard deviation of the firm's ROE over the last 5 year \\
\hline 2-yr loss development & Loss development & $\begin{array}{l}\text { Estimated losses and loss expense incurred } 2 \text { years before current year } \\
\text { and prior year scaled by policyholder's surplus } \times 100\end{array}$ \\
\hline New York license & New York license & $\begin{array}{l}\text { Dummy variable equal to } 1 \text { if firm is licensed in New York State, } \\
0 \text { otherwise }\end{array}$ \\
\hline Cost of capital & Cost of capital & Average of positive ROE over the last 5 years \\
\hline Firm size & Firm size & Logarithm of total admitted assets \\
\hline $\begin{array}{l}\text { Firm affiliated with a } \\
\text { group }\end{array}$ & Group affiliation & $\begin{array}{l}\text { Dummy variable equal to } 1 \text { if the insurer is affiliated with a group, } \\
0 \text { otherwise }\end{array}$ \\
\hline Capital & Capital & Ratio of surplus to total admitted assets \\
\hline
\end{tabular}


Table 3: Summary statistics for all insurers

This table provides summary statistics for the 2,792 firms for the period 1993-2014. Variables are defined in Table 2.

\begin{tabular}{lrrrrrr}
\hline \multicolumn{1}{c}{ Variable } & Obs & \multicolumn{1}{c}{ Mean } & Median & \multicolumn{1}{c}{ Std } & \multicolumn{1}{c}{ Min } & \multicolumn{1}{c}{ Max } \\
\hline Reins & 34,376 & 0.3723 & 0.3205 & 0.2809 & 0.0000 & 0.9992 \\
Liquid & 34,376 & -0.4295 & -0.4143 & 0.2070 & -1.2663 & 0.6950 \\
Insurance leverage & 34,376 & 1.9324 & 1.2409 & 2.7908 & 0.0000 & 33.0000 \\
Geographical concentration & 34,376 & 0.5860 & 0.5943 & 0.3851 & 0.0303 & 1.0000 \\
Regulatory pressure & 34,376 & 0.0282 & 0.0000 & 0.1655 & 0.0000 & 1.0000 \\
Liabilities & 34,376 & 0.1007 & 0.0000 & 0.3009 & 0.0000 & 1.0000 \\
Line concentration & 34,376 & 0.5520 & 0.5000 & 0.2865 & 0.1012 & 1.0000 \\
Reinsurance price & 34,376 & 1.4349 & 1.2020 & 1.2822 & 0.0000 & 12.0000 \\
Tax exemption & 34,376 & 0.2513 & 0.1855 & 0.2445 & 0.0000 & 1.0000 \\
Information asymmetry & 34,376 & 0.1179 & 0.0802 & 0.1351 & 0.0020 & 1.1110 \\
Loss development & 34,376 & -2.9148 & -2.2351 & 19.1562 & -73.7500 & 80.6200 \\
New York license & 34,376 & 0.3217 & 0.0000 & 0.4671 & 0.0000 & 1.0000 \\
Cost of capital & 34,376 & 0.0858 & 0.0828 & 0.1299 & -0.4648 & 0.5280 \\
Firm size & 34,376 & 18.1026 & 18.0298 & 1.9930 & 11.1812 & 25.7466 \\
Group affiliation & 34,376 & 0.6459 & 1.0000 & 0.4783 & 0.0000 & 1.0000 \\
Mix concentration & 34,376 & 0.6719 & 0.6023 & 0.2473 & 0.2505 & 1.0000 \\
Capital & 34,376 & 0.4344 & 0.3912 & 0.1890 & 0.0000 & 1.0000 \\
\hline
\end{tabular}




\section{Table 4: Demand for reinsurance and liquidity creation for all firms during the 1993-2014 period with OLS}

This table provides the results of the OLS fixed effects regression model. The dependent variables are Demand for reinsurance and Liquidity creation ratio. Control variables are defined in Table 2. Heteroscedasticity-consistent standard errors clustered at the firm level are computed and the corresponding $p$-values are reported in parentheses.

\begin{tabular}{|c|c|c|}
\hline Variable & Reins $_{t}$ & Liquid $_{t}$ \\
\hline Reins $t-1$ & $\begin{array}{c}0.6936 \\
(0.000)\end{array}$ & $\begin{array}{c}0.0119 \\
(0.022)\end{array}$ \\
\hline Liquid $_{\mathrm{t}-1}$ & $\begin{array}{c}0.1029 \\
(0.000)\end{array}$ & $\begin{array}{c}0.6725 \\
(0.000)\end{array}$ \\
\hline Insurance leverage $_{t}$ & $\begin{array}{c}0.0107 \\
(0.000)\end{array}$ & \\
\hline Geographical concentration $_{\mathrm{t}}$ & $\begin{array}{l}-0.0351 \\
(0.000)\end{array}$ & $\begin{array}{l}-0.0104 \\
(0.116)\end{array}$ \\
\hline Regulatory pressure $_{t}$ & $\begin{array}{l}-0.0737 \\
(0.000)\end{array}$ & $\begin{array}{c}0.0908 \\
(0.000)\end{array}$ \\
\hline Liabilities $_{\mathrm{t}}$ & $\begin{array}{c}0.0211 \\
(0.000)\end{array}$ & \\
\hline Line concentration $_{\mathrm{t}}$ & $\begin{array}{l}-0.0685 \\
(0.000)\end{array}$ & $\begin{array}{l}-0.0341 \\
(0.000)\end{array}$ \\
\hline Reinsurance price $_{t}$ & $\begin{array}{l}-0.0103 \\
(0.000)\end{array}$ & $\begin{array}{r}0.0048 \\
(0.000)\end{array}$ \\
\hline Tax exemption $_{\mathrm{t}}$ & $\begin{array}{c}0.0010 \\
(0.840)\end{array}$ & $\begin{array}{l}-0.0113 \\
(0.010)\end{array}$ \\
\hline Information asymmetry $\mathrm{t}$ & $\begin{array}{c}0.0223 \\
(0.009)\end{array}$ & $\begin{array}{c}0.0154 \\
(0.064)\end{array}$ \\
\hline Loss development $_{\mathrm{t}}$ & $\begin{array}{l}-0.0001 \\
(0.208)\end{array}$ & $\begin{array}{c}0.0000 \\
(0.540)\end{array}$ \\
\hline New York license $_{t}$ & $\begin{array}{c}0.0280 \\
(0.000)\end{array}$ & $\begin{array}{l}-0.0041 \\
(0.365)\end{array}$ \\
\hline Cost of capital ${ }_{t}$ & $\begin{array}{l}-0.0172 \\
(0.068)\end{array}$ & $\begin{array}{l}-0.0698 \\
(0.000)\end{array}$ \\
\hline Firm size $_{\mathrm{t}}$ & $\begin{array}{l}-0.0097 \\
(0.000)\end{array}$ & $\begin{array}{c}0.0125 \\
(0.000)\end{array}$ \\
\hline Group affiliation $_{\mathrm{t}}$ & $\begin{array}{c}0.0214 \\
(0.000)\end{array}$ & $\begin{array}{l}-0.0046 \\
(0.268)\end{array}$ \\
\hline Mix concentration $_{t}$ & $\begin{array}{c}0.0092 \\
(0.465)\end{array}$ & $\begin{array}{l}-0.0075 \\
(0.432)\end{array}$ \\
\hline Capital $_{\mathrm{t}}$ & $\begin{array}{r}0.1997 \\
(0.000)\end{array}$ & \\
\hline Number of observations & 34,376 & 34,376 \\
\hline Number of firms & 2,792 & 2,792 \\
\hline R-Square (within) & 0.5675 & 0.5242 \\
\hline
\end{tabular}




\section{Table 5: Demand for reinsurance and liquidity creation for all firms during the 1993-2014 period with Generalized Method of Moments}

This table presents the coefficients and $p$-values obtained from the GMM method of estimation. Robust standard errors are used to obtain confidence intervals and the corresponding $p$-values are reported in parentheses. It also documents the $p$-value of the specification J-test. The standard GMM is rejected at all significance levels. Control variables are defined in Table 2.

\begin{tabular}{|c|c|c|c|c|c|c|}
\hline \multirow[b]{2}{*}{ Variable } & \multicolumn{2}{|c|}{ Standard GMM } & \multicolumn{2}{|c|}{$\begin{array}{c}\text { Tikhonov regularized } \\
\text { GMM }\end{array}$} & \multicolumn{2}{|c|}{$\begin{array}{l}\text { Landweber-Fridman } \\
\text { regularized GMM }\end{array}$} \\
\hline & Reins $_{t}$ & Liquid $_{t}$ & Reins $_{t}$ & Liquid $_{t}$ & Reins $_{t}$ & Liquid $_{t}$ \\
\hline Reins $\mathrm{t}-1$ & $\begin{array}{c}0.8258 \\
(0.000)\end{array}$ & $\begin{array}{l}0.0066 \\
(0.000)\end{array}$ & $\begin{array}{c}0.8163 \\
(0.000)\end{array}$ & $\begin{array}{l}0.0351 \\
(0.000)\end{array}$ & $\begin{array}{c}0.7133 \\
(0.000)\end{array}$ & $\begin{array}{c}0.0383 \\
(0.000)\end{array}$ \\
\hline Liquid $_{t-1}$ & $\begin{array}{c}0.008 \\
(0.000)\end{array}$ & $\begin{array}{c}0.8264 \\
(0.000)\end{array}$ & $\begin{array}{c}0.0751 \\
(0.000)\end{array}$ & $\begin{array}{c}0.6058 \\
(0.000)\end{array}$ & $\begin{array}{c}0.0764 \\
(0.000)\end{array}$ & $\begin{array}{c}0.5715 \\
(0.000)\end{array}$ \\
\hline Insurance leverage $_{t}$ & $\begin{array}{r}0.0030 \\
(0.000)\end{array}$ & & $\begin{array}{c}0.0030 \\
(0.000)\end{array}$ & & $\begin{array}{c}0.0046 \\
(0.000)\end{array}$ & \\
\hline Geographical concentration $_{t}$ & $\begin{array}{l}-2.6 \mathrm{E}-4 \\
(0.3020)\end{array}$ & $\begin{array}{l}-0.0110 \\
(0.1797)\end{array}$ & $\begin{array}{l}-0.0288 \\
(0.000)\end{array}$ & $\begin{array}{l}-0.0239 \\
(0.3776)\end{array}$ & $\begin{array}{l}-0.0325 \\
(0.000)\end{array}$ & $\begin{array}{l}-0.01563 \\
(0.3385)\end{array}$ \\
\hline Regulatory pressure $_{\mathrm{t}}$ & $\begin{array}{l}-0.0213 \\
(0.000)\end{array}$ & $\begin{array}{c}0.0354 \\
(0.000)\end{array}$ & $\begin{array}{l}-0.1138 \\
(0.000)\end{array}$ & $\begin{array}{l}0.04385 \\
(0.000)\end{array}$ & $\begin{array}{l}-0.0845 \\
(0.000)\end{array}$ & $\begin{array}{c}0.0446 \\
(0.000)\end{array}$ \\
\hline Liabilities $_{\mathrm{t}}$ & $\begin{array}{r}6.05 \mathrm{E}-4 \\
(0.1599)\end{array}$ & & $\begin{array}{c}0.0310 \\
(0.000)\end{array}$ & & $\begin{array}{c}0.00651 \\
(0.0931)\end{array}$ & \\
\hline Line concentration $_{\mathrm{t}}$ & $\begin{array}{l}-0.0158 \\
(0.000)\end{array}$ & $\begin{array}{l}-0.0054 \\
(0.000)\end{array}$ & $\begin{array}{l}-0.0812 \\
(0.000)\end{array}$ & $\begin{array}{l}-0.0370 \\
(0.000)\end{array}$ & $\begin{array}{l}-0.0318 \\
(0.000)\end{array}$ & $\begin{array}{l}-0.0216 \\
(0.000)\end{array}$ \\
\hline Reinsurance price $_{t}$ & $\begin{array}{l}-0.0012 \\
(0.000)\end{array}$ & $\begin{array}{c}0.0012 \\
(0.000)\end{array}$ & $\begin{array}{l}-0.0128 \\
(0.000)\end{array}$ & $\begin{array}{c}0.0229 \\
(0.000)\end{array}$ & $\begin{array}{l}-0.0073 \\
(0.000)\end{array}$ & $\begin{array}{c}0.0089 \\
(0.000)\end{array}$ \\
\hline Tax exemption $_{\mathrm{t}}$ & $\begin{array}{r}0.0089 \\
(0.000)\end{array}$ & $\begin{array}{l}-0.0049 \\
(0.000)\end{array}$ & $\begin{array}{c}0.0374 \\
(0.000)\end{array}$ & $\begin{array}{l}-0.0053 \\
(0.000)\end{array}$ & $\begin{array}{c}0.0963 \\
(0.000)\end{array}$ & $\begin{array}{l}-0.0058 \\
(0.000)\end{array}$ \\
\hline Information asymmetry $\mathrm{t}$ & $\begin{array}{r}0.0107 \\
(0.000)\end{array}$ & $\begin{array}{c}0.0275 \\
(0.4013)\end{array}$ & $\begin{array}{c}0.004 \\
(0.000)\end{array}$ & $\begin{array}{l}-0.0260 \\
(0.3092)\end{array}$ & $\begin{array}{c}0.0236 \\
(0.000)\end{array}$ & $\begin{array}{l}-0.0081 \\
(0.3564)\end{array}$ \\
\hline Loss development $_{\mathrm{t}}$ & $\begin{array}{l}2.07 \mathrm{E}-5 \\
(0.000)\end{array}$ & $\begin{array}{c}0.0122 \\
(0.4042)\end{array}$ & $\begin{array}{c}8 \mathrm{E}-5 \\
(0.0785)\end{array}$ & $\begin{array}{c}0.0172 \\
(0.3296)\end{array}$ & $\begin{array}{c}1.25 \mathrm{E}-4 \\
(0.0890)\end{array}$ & $\begin{array}{c}0.0118 \\
(0.2561)\end{array}$ \\
\hline New York license ${ }_{t}$ & $\begin{array}{c}0.0084 \\
(0.000)\end{array}$ & $\begin{array}{r}5.97 \mathrm{E}-4 \\
(0.2099)\end{array}$ & $\begin{array}{c}0.0530 \\
(0.000)\end{array}$ & $\begin{array}{l}-2.5 \mathrm{E}-4 \\
(0.3906)\end{array}$ & $\begin{array}{c}0.0545 \\
(0.000)\end{array}$ & $\begin{array}{l}-1.0 \mathrm{E}-4 \\
(0.4252)\end{array}$ \\
\hline Cost of capital $_{t}$ & $\begin{array}{l}-0.0107 \\
(0.000)\end{array}$ & $\begin{array}{l}-0.0041 \\
(0.000)\end{array}$ & $\begin{array}{l}-0.1196 \\
(0.000)\end{array}$ & $\begin{array}{l}-0.0287 \\
(0.000)\end{array}$ & $\begin{array}{l}-0.0685 \\
(0.000)\end{array}$ & $\begin{array}{l}-0.0362 \\
(0.000)\end{array}$ \\
\hline Firm size $_{t}$ & $\begin{array}{l}-0.0020 \\
(0.0912)\end{array}$ & $\begin{array}{c}0.0218 \\
(0.000)\end{array}$ & $\begin{array}{l}-0.0055 \\
(0.000)\end{array}$ & $\begin{array}{l}0.01272 \\
(0.000)\end{array}$ & $\begin{array}{l}-0.0108 \\
(0.000)\end{array}$ & $\begin{array}{c}0.0226 \\
(0.000)\end{array}$ \\
\hline Group affiliation $_{\mathrm{t}}$ & $\begin{array}{r}0.0157 \\
(0.000)\end{array}$ & $\begin{array}{l}-0.0034 \\
(0.1543)\end{array}$ & $\begin{array}{r}0.0357 \\
(0.000)\end{array}$ & $\begin{array}{l}-0.0047 \\
(0.4241)\end{array}$ & $\begin{array}{c}0.0151 \\
(0.000)\end{array}$ & $\begin{array}{l}-0.0066 \\
(0.2648)\end{array}$ \\
\hline Mix concentration $_{\mathrm{t}}$ & $\begin{array}{c}0.0202 \\
(0.1372)\end{array}$ & $\begin{array}{l}-0.0040 \\
(0.1141)\end{array}$ & $\begin{array}{c}0.0536 \\
(0.1962)\end{array}$ & $\begin{array}{l}-0.0117 \\
(0.3144)\end{array}$ & $\begin{array}{c}0.0152 \\
(0.0982)\end{array}$ & $\begin{array}{l}-0.0190 \\
(0.3496)\end{array}$ \\
\hline Capital $_{\mathrm{t}}$ & $\begin{array}{c}0.0238 \\
(0.000)\end{array}$ & & $\begin{array}{c}0.0758 \\
(0.000)\end{array}$ & & $\begin{array}{r}0.0817 \\
(0.000)\end{array}$ & \\
\hline$p$-value of the $\mathrm{J}$-test & 0.0000 & 0.0000 & 0.2058 & 0.2568 & 0.5436 & 0.4602 \\
\hline Number of observations & & & & & & \\
\hline Number of firms & & & & & & \\
\hline
\end{tabular}


Table 6: Test of variable exogeneity for the ML-SEM model

All insurers present each year during the 1992-2014 period

p-values for the test: $H_{0}: \phi_{j k}=0$ are reported. Variables are defined in Table 2.

\begin{tabular}{l|cc}
\hline \multicolumn{1}{c|}{ Variable } & Reins $_{\mathrm{t}}$ & Liquid $_{\mathrm{t}}$ \\
\hline Insurance leverage $_{\mathrm{t}+1}$ & 0.015 & \\
Regulatory pressure $_{\mathrm{t}+1}$ & 0.050 & 0.104 \\
Reinsurance price $_{\mathrm{t}+1}$ & 0.129 & 0.019 \\
Cost of capital $_{\mathrm{t}+1}$ & & 0.141 \\
Tax exemption $_{\mathrm{t}+1}$ & 0.103 & 0.312 \\
Information asymmetry $_{\mathrm{t}+1}$ & & 0.000 \\
Capital $_{\mathrm{t}+1}$ & 0.560 & \\
\hline
\end{tabular}


Table 7: Estimates with ML-SME model for all insurers present each year during the 1992-2014 period with standardized control variables.

All goodness of fit measures have acceptable values. Variables are defined in Table 2.

\begin{tabular}{|c|c|c|}
\hline Variable & Reins $_{t}$ & Liquid $_{\mathrm{t}}$ \\
\hline Reins $t-1$ & $\begin{array}{r}0.8726 \\
(0.000)\end{array}$ & $\begin{array}{r}0.0590 \\
(0.000)\end{array}$ \\
\hline Liquid $_{t-1}$ & $\begin{array}{r}0.0846 \\
(0.000)\end{array}$ & $\begin{array}{c}0.8988 \\
(0.000)\end{array}$ \\
\hline Insurance leverage $_{t}$ & $\begin{array}{r}0.0584 \\
(0.000)\end{array}$ & \\
\hline Regulatory pressure $_{\mathrm{t}}$ & $\begin{array}{l}-0.0187 \\
(0.000)\end{array}$ & $\begin{array}{r}0.0259 \\
(0.000)\end{array}$ \\
\hline Reinsurance price $_{t}$ & $\begin{array}{l}-0.0427 \\
(0.000)\end{array}$ & $\begin{array}{c}0.0011 \\
(0.821)\end{array}$ \\
\hline Cost of capital $_{t}$ & & $\begin{array}{l}-0.0336 \\
(0.000)\end{array}$ \\
\hline Tax exemption $_{t}$ & $\begin{array}{r}0.0063 \\
(0.205)\end{array}$ & $\begin{array}{r}0.0019 \\
(0.728)\end{array}$ \\
\hline Information asymmetry $\mathrm{t}$ & & $\begin{array}{l}-0.0140 \\
(0.009)\end{array}$ \\
\hline Capital $_{\mathrm{t}}$ & $\begin{array}{r}0.1040 \\
(0.000)\end{array}$ & \\
\hline Number of firms & 489 & \\
\hline $\begin{array}{l}\text { Number of observations } \\
\text { Goodness of Fit Model }\end{array}$ & 10,269 & \\
\hline RMSEA & 0.043 & 0.049 \\
\hline CFI & 0.927 & 0.904 \\
\hline TLI & 0.902 & 0.871 \\
\hline SRMR & 0.015 & 0.027 \\
\hline
\end{tabular}


Table 8: Estimation of Table 7 model with GMM from 1992 to 2014 for all insurers

This table presents the coefficients and $p$-values obtained from the GMM method of estimation. Robust standard errors are used to obtain confidence intervals and the corresponding $p$-values are reported in parentheses. It also documents the $p$-value of the specification J-test. The standard GMM is rejected at all significance levels.

\begin{tabular}{|c|c|c|c|c|c|c|}
\hline \multirow[b]{2}{*}{ Variable } & \multicolumn{2}{|c|}{ Standard GMM } & \multicolumn{2}{|c|}{$\begin{array}{c}\text { Tikhonov regularized } \\
\text { GMM }\end{array}$} & \multicolumn{2}{|c|}{$\begin{array}{l}\text { Landweber-Fridman } \\
\text { regularized GMM }\end{array}$} \\
\hline & Reins $_{t}$ & Liquid $_{t}$ & Reins $_{t}$ & Liquid $_{t}$ & Reins $_{t}$ & Liquid $_{\mathrm{t}}$ \\
\hline Reins $\mathrm{t}-1$ & $\begin{array}{c}0.9580 \\
(0.0000)\end{array}$ & $\begin{array}{c}0.0400 \\
(0.0000)\end{array}$ & $\begin{array}{c}0.8682 \\
(0.0000)\end{array}$ & $\begin{array}{c}0.0490 \\
(0.0000)\end{array}$ & $\begin{array}{c}0.9077 \\
(0.0000)\end{array}$ & $\begin{array}{c}0.0655 \\
(0.0000)\end{array}$ \\
\hline Liquid $_{\mathrm{t}-1}$ & $\begin{array}{c}0.0400 \\
(0.0000)\end{array}$ & $\begin{array}{c}0.9602 \\
(0.0000)\end{array}$ & $\begin{array}{c}0.0804 \\
(0.0000)\end{array}$ & $\begin{array}{c}0.8962 \\
(0.0000)\end{array}$ & $\begin{array}{c}0.0797 \\
(0.0000)\end{array}$ & $\begin{array}{c}0.9297 \\
(0.0000)\end{array}$ \\
\hline Insurance leverage $_{t}$ & $\begin{array}{c}0.0200 \\
(0.0000)\end{array}$ & & $\begin{array}{l}0.0520 \\
(0.0000)\end{array}$ & & $\begin{array}{c}0.0370 \\
(0.0000)\end{array}$ & \\
\hline Regulatory pressure $_{\mathrm{t}}$ & $\begin{array}{l}-0.0200 \\
(0.0000)\end{array}$ & $\begin{array}{c}0.0100 \\
(0.0000)\end{array}$ & $\begin{array}{l}-0.0451 \\
(0.0000)\end{array}$ & $\begin{array}{c}0.0489 \\
(0.0000)\end{array}$ & $\begin{array}{l}-0.0351 \\
(0.0001)\end{array}$ & $\begin{array}{c}0.0361 \\
(0.0000)\end{array}$ \\
\hline Reinsurance price $_{t}$ & $\begin{array}{l}-0.020 \\
(0.0000)\end{array}$ & $\begin{array}{c}0.0042 \\
(0.4380)\end{array}$ & $\begin{array}{l}-0.0352 \\
(0.0000)\end{array}$ & $\begin{array}{c}0.0064 \\
(0.678)\end{array}$ & $\begin{array}{l}-0.0352 \\
(0.0000)\end{array}$ & $\begin{array}{l}0.0044 \\
(0.703)\end{array}$ \\
\hline Cost of capital ${ }_{t}$ & & $\begin{array}{l}-0.0330 \\
(0.0000)\end{array}$ & & $\begin{array}{l}-0.0654 \\
(0.0000)\end{array}$ & & $\begin{array}{l}-0.0620 \\
(0.0000)\end{array}$ \\
\hline Tax exemption $_{t}$ & $\begin{array}{c}0.0070 \\
(0.3800)\end{array}$ & $\begin{array}{c}0.0012 \\
(0.2048)\end{array}$ & $\begin{array}{c}0.0030 \\
(0.6000)\end{array}$ & $\begin{array}{c}0.0075 \\
(0.4030)\end{array}$ & $\begin{array}{c}0.0040 \\
(0.5440)\end{array}$ & $\begin{array}{c}0.0089 \\
(0.483)\end{array}$ \\
\hline Information asymmetry $\mathrm{t}$ & & $\begin{array}{l}-0.0488 \\
(0.0490)\end{array}$ & & $\begin{array}{l}-0.0293 \\
(0.0000)\end{array}$ & & $\begin{array}{l}-0.0240 \\
(0.0000)\end{array}$ \\
\hline Capital $_{\mathrm{t}}$ & $\begin{array}{c}0.1350 \\
(0.045)\end{array}$ & & $\begin{array}{c}0.1437 \\
(0.0000)\end{array}$ & & $\begin{array}{c}0.1225 \\
(0.0000)\end{array}$ & \\
\hline$p$-value of the $\mathrm{J}$-test & 0.0046 & 0.0026 & 0.7847 & 0.7540 & 0.8953 & 0.7985 \\
\hline Number of observations & & & 10 & & & \\
\hline Number of firms & & & & 39 & & \\
\hline
\end{tabular}




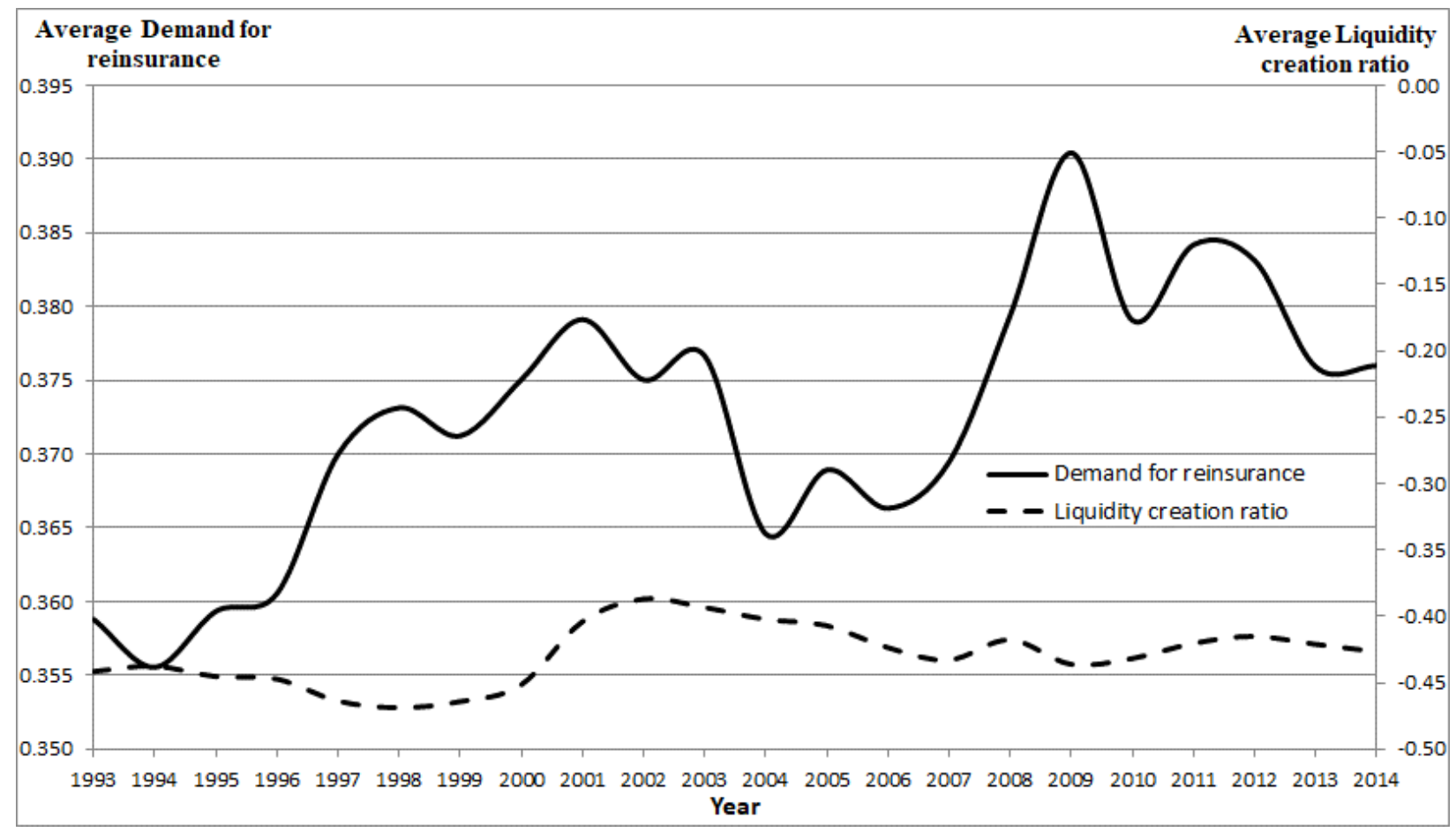

Figure 1: All insurers

Average demand for reinsurance and average liquidity creation ratio by year 


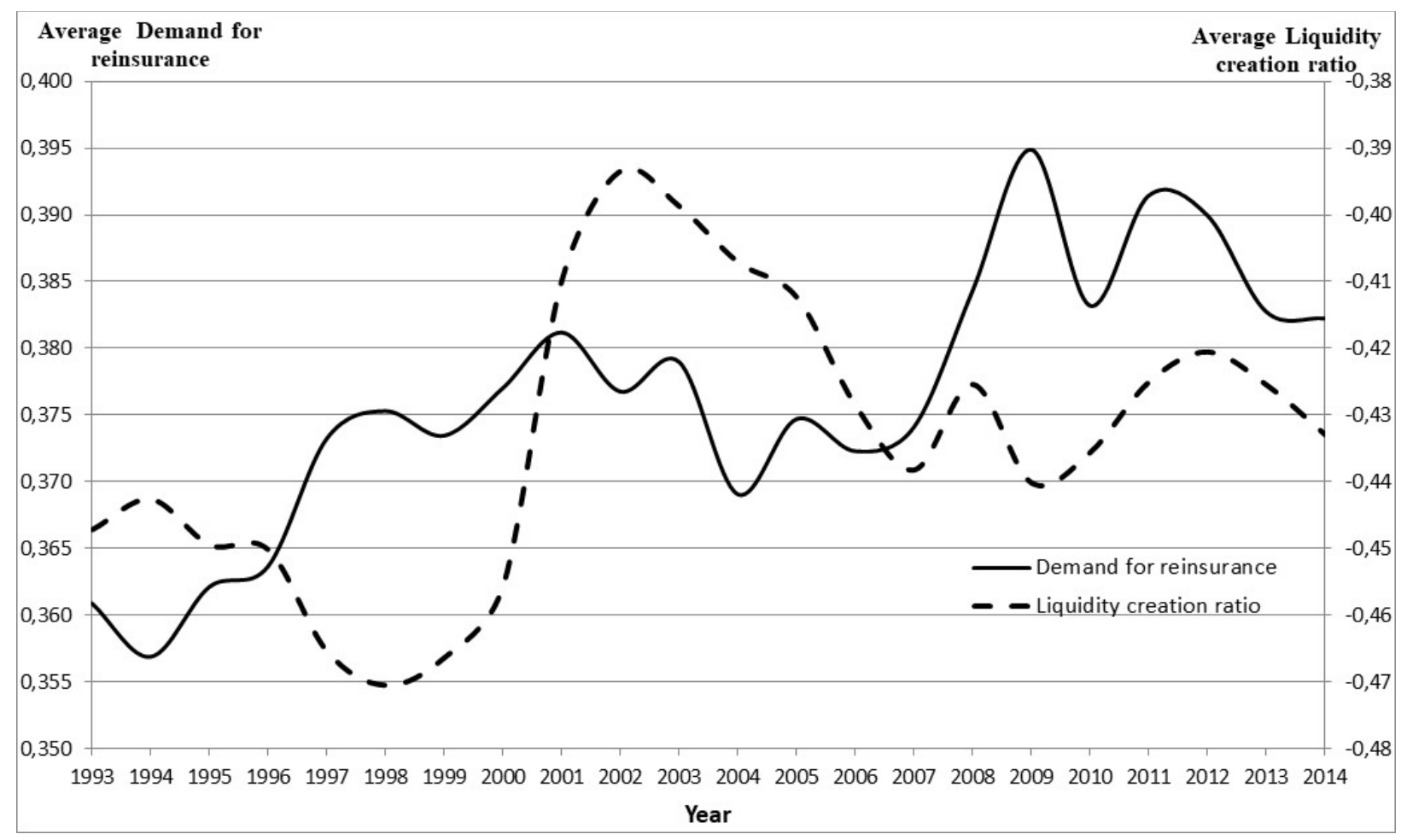

Figure 2: Small insurers

Average demand for reinsurance and liquidity creation ratio by year 


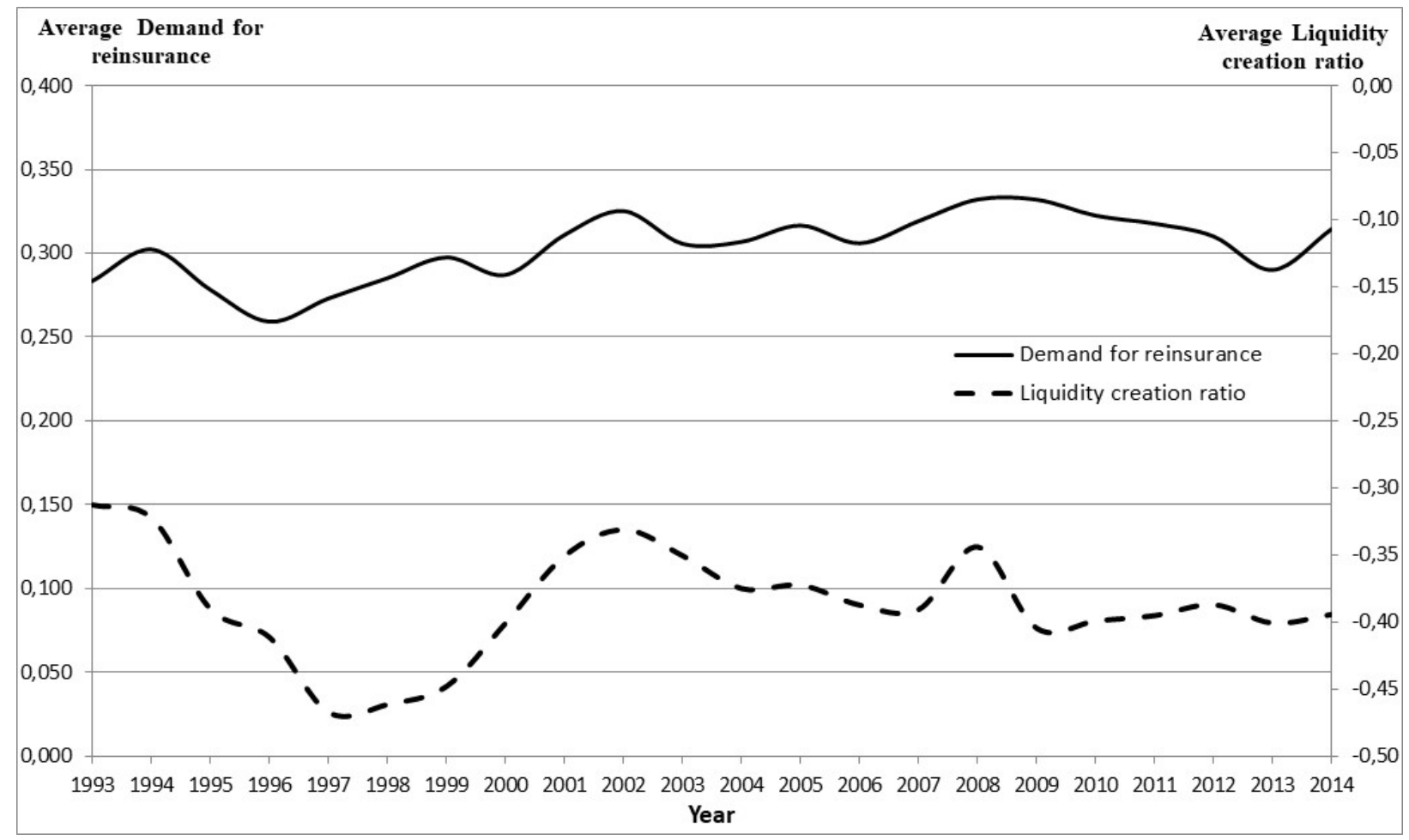

Figure 3: Large insurers

Average demand for reinsurance and liquidity creation ratio by year 


\section{Appendix}

\section{A1 Fit indices for the ML-SME model}

Root Mean Square Error of Approximation (RMSEA-SB) Index: An index of the difference between the observed covariance matrix per degree of freedom and the hypothesized covariance matrix. A value less than .08 is generally considered a good fit (Hu and Bentler, 1999). For Browne and Cudeck (1993), RMSEA < 0.06 is a good fit. The Satorra-Bentler (SB) scaled test is robust to nonnormality.

The Comparative Fit Index (CFI-SB) is an incremental fit index that produces values between $0-1$; high values are indicators of good fit. An acceptable fit is provided when the CFI value is larger than 0.95 (Schermelleh-Engel et al., 2003). This index is relatively independent from sample size and yields better performance when small samples are studied (Chen, 2007; Hu and Bentler, 1998). The Satorra-Bentler (SB) scaled test is robust to nonnormality.

The Tucker-Lewis Index (TLI-SB) is an incremental index that is not required to be between 0 and 1. A higher TLI value indicates better fit, and values larger than 0.95 are interpreted as acceptable fit. The Satorra-Bentler (SB) scaled test is robust to nonnormality.

The Standardized Root Mean Square Residual (SRMR) is a measure of the average difference between the observed and model implied correlations. It will be close to 0 when the model fits well. Hu and Bentler (1999) suggest values of about .08 or under. 


\section{A2 Additional tables}

Table 3a: Summary statistics - Large insurers

This table provides summary statistics for the 100 large firms during the period 1993-2014. Variables are defined in Table 2.

\begin{tabular}{lrrrrrr}
\hline \multicolumn{1}{c}{ Variable } & Obs & Mean & Median & Std & Min & \multicolumn{1}{c}{ Max } \\
\hline Demand for reinsurance & 1,236 & 0.3055 & 0.2472 & 0.2549 & 0.0000 & 0.9486 \\
Liquidity creation ratio & 1,236 & -0.3854 & -0.3810 & 0.1388 & -0.9915 & 0.2610 \\
Insurance leverage & 1,236 & 0.7712 & 0.5821 & 0.8243 & 0.0000 & 7.1079 \\
Geographical concentration & 1,236 & 0.1835 & 0.0733 & 0.2632 & 0.0327 & 1.0000 \\
Regulatory pressure & 1,236 & 0.0146 & 0.0000 & 0.1198 & 0.0000 & 1.0000 \\
Liabilities & 1,236 & 0.3317 & 0.0000 & 0.4710 & 0.0000 & 1.0000 \\
Line concentration & 1,236 & 0.3766 & 0.3060 & 0.2377 & 0.1038 & 1.0000 \\
Reinsurance price & 1,236 & 1.3769 & 1.1513 & 1.5169 & 0.0000 & 12.0000 \\
Tax exemption & 1,236 & 0.3841 & 0.3766 & 0.2076 & 0.0000 & 0.9782 \\
Information asymmetry & 1,236 & 0.0963 & 0.0710 & 0.0877 & 0.0028 & 1.1110 \\
Loss development & 1,236 & 0.5619 & -1.7156 & 17.1751 & -73.7500 & 80.6200 \\
New York license & 1,236 & 0.8115 & 1.0000 & 0.3913 & 0.0000 & 1.0000 \\
Cost of capital & 1,236 & 0.1176 & 0.1155 & 0.1011 & -0.4648 & 0.4745 \\
Firm size & 1,236 & 22.7750 & 22.5459 & 0.7757 & 21.8253 & 25.7466 \\
Group affiliation & 1,236 & 0.9693 & 1.0000 & 0.1727 & 0.0000 & 1.0000 \\
Mix concentration & 1,236 & 0.5549 & 0.4971 & 0.2028 & 0.2567 & 1.0000 \\
Capital & 1,236 & 0.3671 & 0.3348 & 0.1472 & 0.0172 & 0.9893 \\
\hline
\end{tabular}




\section{Table 3b: Summary statistics - Medium insurers}

This table provides summary statistics for the 235 medium firms during the period 1993-2014. Variables are defined in Table 2.

\begin{tabular}{lrrrrrr}
\hline \multicolumn{1}{c}{ Variable } & Obs & Mean & Median & Std & Min & Max \\
\hline Demand for reinsurance & 1,993 & 0.3603 & 0.3291 & 0.2578 & 0.0000 & 0.9958 \\
Liquidity creation ratio & 1,993 & -0.3886 & -0.3862 & 0.1396 & -0.9061 & 0.2396 \\
Insurance leverage & 1,993 & 1.2150 & 0.9508 & 1.1176 & 0.0000 & 13.2395 \\
Geographical concentration & 1,993 & 0.3364 & 0.1374 & 0.3592 & 0.0320 & 1.0000 \\
Regulatory pressure & 1,993 & 0.0146 & 0.0000 & 0.1198 & 0.0000 & 1.0000 \\
Liabilities & 1,993 & 0.1766 & 0.0000 & 0.3814 & 0.0000 & 1.0000 \\
Line concentration & 1,993 & 0.4293 & 0.3366 & 0.2646 & 0.1012 & 1.0000 \\
Reinsurance price & 1,993 & 1.2855 & 1.1655 & 0.8095 & 0.0000 & 12.0000 \\
Tax exemption & 1,993 & 0.3623 & 0.3398 & 0.2375 & 0.0000 & 0.9922 \\
Information asymmetry & 1,993 & 0.1029 & 0.0744 & 0.1204 & 0.0024 & 1.1110 \\
Loss development & 1,993 & -2.8469 & -3.2536 & 16.2065 & -73.7500 & 80.6200 \\
New York license & 1,993 & 0.6307 & 1.0000 & 0.4827 & 0.0000 & 1.0000 \\
Cost of capital & 1,993 & 0.1125 & 0.1051 & 0.1180 & -0.4648 & 0.5280 \\
Firm size & 1,993 & 21.1905 & 21.1692 & 0.2923 & 20.7238 & 21.8108 \\
Group affiliation & 1,993 & 0.9498 & 1.0000 & 0.2184 & 0.0000 & 1.0000 \\
Mix concentration & 1,993 & 0.6059 & 0.5242 & 0.2290 & 0.2521 & 1.0000 \\
Capital & 1,993 & 0.3595 & 0.3303 & 0.1358 & 0.0469 & 0.9986 \\
\hline
\end{tabular}




\section{Table 3c: Summary statistics - Small insurers}

This table provides summary statistics for the 2,658 small firms during the period 1993-2014. Variables are defined in Table 2.

\begin{tabular}{lrrrrrr}
\hline \multicolumn{1}{c}{ Variable } & Obs & Mean & Median & Std & Min & Max \\
\hline Demand for reinsurance & 30,753 & 0.3758 & 0.3229 & 0.2832 & 0.0000 & 0.9992 \\
Liquidity creation ratio & 30,753 & -0.4346 & -0.4191 & 0.2128 & -1.2663 & 0.6950 \\
Insurance leverage & 30,753 & 2.0328 & 1.3129 & 2.9057 & 0.0000 & 33.0000 \\
Geographical concentration & 30,753 & 0.6220 & 0.6940 & 0.3747 & 0.0303 & 1.0000 \\
Regulatory pressure & 30,753 & 0.0298 & 0.0000 & 0.1701 & 0.0000 & 1.0000 \\
Liabilities & 30,753 & 0.0848 & 0.0000 & 0.2786 & 0.0000 & 1.0000 \\
Line concentration & 30,753 & 0.5680 & 0.5088 & 0.2852 & 0.1139 & 1.0000 \\
Reinsurance price & 30,753 & 1.4481 & 1.2083 & 1.2976 & 0.0000 & 12.0000 \\
Tax exemption & 30,753 & 0.2376 & 0.1646 & 0.2426 & 0.0000 & 1.0000 \\
Information asymmetry & 30,753 & 0.1197 & 0.0811 & 0.1372 & 0.0020 & 1.1110 \\
Loss development & 30,753 & -3.1064 & -2.1991 & 19.3894 & -73.7500 & 80.6200 \\
New York license & 30,753 & 0.2774 & 0.0000 & 0.4477 & 0.0000 & 1.0000 \\
Cost of capital & 30,753 & 0.0826 & 0.0797 & 0.1313 & -0.4648 & 0.5280 \\
Firm size & 30,753 & 17.6779 & 17.7570 & 1.6199 & 11.1812 & 20.7212 \\
Group affiliation & 30,753 & 0.6094 & 1.0000 & 0.4879 & 0.0000 & 1.0000 \\
Mix concentration & 30,753 & 0.6810 & 0.6167 & 0.2483 & 0.2505 & 1.0000 \\
Capital & 30,753 & 0.4430 & 0.4002 & 0.1921 & 0.0000 & 1.0000 \\
\hline
\end{tabular}


Table 3d: Number of years of observations for each firm by period

\begin{tabular}{c|rr|rr|rr}
\hline \multirow{2}{*}{$\begin{array}{c}\text { Number of years of } \\
\text { observation }\end{array}$} & \multicolumn{2}{|c|}{$1992-1999$} & \multicolumn{2}{c|}{$2000-2007$} & \multicolumn{2}{c}{$2008-2014$} \\
\hline 4 & 156 & 8.30 & 169 & 9.84 & 191 & 11.29 \\
5 & 218 & 11.60 & 167 & 9.73 & 192 & 11.35 \\
6 & 152 & 8.09 & 163 & 9.49 & 201 & 11.88 \\
7 & 281 & 14.95 & 155 & 9.03 & 1,108 & 65.48 \\
8 & 1,072 & 57.05 & 1,063 & 61.91 & ------- & ------- \\
Number of firms & 1,879 & 100.00 & 1,717 & 100.00 & 1,692 & 100.00 \\
\hline
\end{tabular}




\section{Table 4a: Large Insurers with OLS model}

This table provides the results of the OLS fixed effects regressions. The dependent variables are Demand for reinsurance and Liquidity creation ratio. All the variables are defined in Table 2. Heteroscedasticityconsistent standard errors clustered at the firm level are computed and the corresponding $p$-values are reported in parentheses.

\begin{tabular}{|c|c|c|}
\hline Variable & Demand for reinsurance $_{t}$ & Liquidity creation ratio $\mathrm{t}_{\mathrm{t}}$ \\
\hline Demand of reinsurance $t-1$ & $\begin{array}{c}0.7468 \\
(0.000)\end{array}$ & $\begin{array}{l}-0.0404 \\
(0.210)\end{array}$ \\
\hline Liquidity creation ratio $t-1$ & $\begin{array}{c}0.0463 \\
(0.158)\end{array}$ & $\begin{array}{c}0.6863 \\
(0.000)\end{array}$ \\
\hline Insurance leverage & $\begin{array}{c}0.0271 \\
(0.004)\end{array}$ & \\
\hline Geographical concentration & $\begin{array}{l}-0.0793 \\
(0.000)\end{array}$ & $\begin{array}{l}-0.0984 \\
(0.000)\end{array}$ \\
\hline Regulatory pressure & $\begin{array}{c}0.0008 \\
(0.942)\end{array}$ & $\begin{array}{c}0.0083 \\
(0.243)\end{array}$ \\
\hline Liabilities & $\begin{array}{c}0.0062 \\
(0.417)\end{array}$ & \\
\hline Line concentration & $\begin{array}{l}-0.1372 \\
(0.000)\end{array}$ & $\begin{array}{r}0.0127 \\
(0.586)\end{array}$ \\
\hline Reinsurance price & $\begin{array}{l}-0.0086 \\
(0.055)\end{array}$ & $\begin{array}{c}0.0000 \\
(1.000)\end{array}$ \\
\hline Tax exemption & $\begin{array}{l}-0.0061 \\
(0.803)\end{array}$ & $\begin{array}{l}-0.0232 \\
(0.131)\end{array}$ \\
\hline Information asymmetry & $\begin{array}{l}-0.0128 \\
(0.713)\end{array}$ & $\begin{array}{r}0.1307 \\
(0.000)\end{array}$ \\
\hline Loss development & $\begin{array}{l}-0.0003 \\
(0.140)\end{array}$ & $\begin{array}{r}0.0001 \\
(0.533)\end{array}$ \\
\hline New York license & $\begin{array}{l}-0.0340 \\
(0.019)\end{array}$ & $\begin{array}{c}0.0190 \\
(0.205)\end{array}$ \\
\hline Cost of capital & $\begin{array}{c}0.0221 \\
(0.610)\end{array}$ & $\begin{array}{c}0.0047 \\
(0.857)\end{array}$ \\
\hline Firm size & $\begin{array}{c}0.0021 \\
(0.837)\end{array}$ & $\begin{array}{l}-0.0023 \\
(0.744)\end{array}$ \\
\hline Group affiliation & $\begin{array}{c}0.0111 \\
(0.649)\end{array}$ & $\begin{array}{l}-0.0369 \\
(0.196)\end{array}$ \\
\hline Mix concentration & $\begin{array}{c}0.0996 \\
(0.010)\end{array}$ & $\begin{array}{c}0.0039 \\
(0.895)\end{array}$ \\
\hline Capital & $\begin{array}{c}0.2175 \\
(0.001)\end{array}$ & \\
\hline Number of observations & 1,236 & 1,236 \\
\hline Number of firms & 100 & 100 \\
\hline R-Square (within) & 0.5727 & \\
\hline
\end{tabular}




\section{Table 4b: Medium insurers with OLS model Demand for reinsurance and Liquidity creation}

This table provides the results of the OLS fixed effects regressions. The dependent variables are Demand for reinsurance and Liquidity creation ratio. All the variables are defined in Table 2. Heteroscedasticity-consistent standard errors clustered at the firm level are computed and the corresponding $p$-values are reported in parentheses.

\begin{tabular}{|c|c|c|}
\hline Variable & Demand for reinsurance $t_{t}$ & Liquidity creation ratio $\mathrm{t}$ \\
\hline Demand of reinsurance $t_{-1}$ & $\begin{array}{c}0.6281 \\
(0.000)\end{array}$ & $\begin{array}{l}-0.0046 \\
(0.850)\end{array}$ \\
\hline Liquidity creation ratio $\mathrm{t}-1$ & $\begin{array}{l}0.1168 \\
0.005\end{array}$ & $\begin{array}{c}0.6940 \\
(0.000)\end{array}$ \\
\hline Insurance leverage & $\begin{array}{c}0.0206 \\
(0.000)\end{array}$ & \\
\hline Geographical concentration & $\begin{array}{l}-0.0175 \\
(0.669)\end{array}$ & $\begin{array}{c}0.0167 \\
(0.280)\end{array}$ \\
\hline Regulatory pressure & $\begin{array}{l}-0.0151 \\
(0.167)\end{array}$ & $\begin{array}{c}0.0765 \\
(0.000)\end{array}$ \\
\hline Liabilities & $\begin{array}{c}0.0002 \\
(0.985)\end{array}$ & \\
\hline Line concentration & $\begin{array}{c}0.0340 \\
(0.519)\end{array}$ & $\begin{array}{c}0.0129 \\
(0.602)\end{array}$ \\
\hline Reinsurance price & $\begin{array}{l}-0.0298 \\
(0.000)\end{array}$ & $\begin{array}{c}0.0048 \\
(0.129)\end{array}$ \\
\hline Tax exemption & $\begin{array}{l}-0.0101 \\
(0.589)\end{array}$ & $\begin{array}{c}0.0169 \\
(0.191)\end{array}$ \\
\hline Information asymmetry & $\begin{array}{c}0.0084 \\
(0.798)\end{array}$ & $\begin{array}{c}0.0138 \\
(0.360)\end{array}$ \\
\hline Loss development & $\begin{array}{l}-0.0001 \\
(0.469)\end{array}$ & $\begin{array}{c}0.0005 \\
(0.000)\end{array}$ \\
\hline New York license & $\begin{array}{c}0.0542 \\
(0.020)\end{array}$ & $\begin{array}{c}0.0048 \\
(0.752)\end{array}$ \\
\hline Cost of capital & $\begin{array}{c}0.0123 \\
(0.686)\end{array}$ & $\begin{array}{l}-0.0210 \\
(0.306)\end{array}$ \\
\hline Firm size & $\begin{array}{l}-0.0193 \\
(0.167)\end{array}$ & $\begin{array}{c}0.0223 \\
(0.013)\end{array}$ \\
\hline Group affiliation & $\begin{array}{c}0.0042 \\
(0.587)\end{array}$ & $\begin{array}{c}0.0172 \\
(0.007)\end{array}$ \\
\hline Mix concentration & $\begin{array}{l}-0.0393 \\
(0.314)\end{array}$ & $\begin{array}{l}-0.0126 \\
(0.583)\end{array}$ \\
\hline Capital & $\begin{array}{r}0.3432 \\
(0.000)\end{array}$ & \\
\hline Number of observations & 1,993 & 1,993 \\
\hline Number of firms & 235 & 235 \\
\hline R-Square (within) & 0.4688 & 0.5378 \\
\hline
\end{tabular}




\section{Table 4c: Small insurers with OLS model Demand for reinsurance and Liquidity creation}

This table provides the results of the OLS fixed effects regressions. The dependent variables are Demand for reinsurance and Liquidity creation ratio. Control variables are defined in Table 2. Heteroscedasticity-consistent standard errors clustered at the firm level are computed and the corresponding $p$-values are reported in parentheses.

\begin{tabular}{|c|c|c|}
\hline Variable & Demand for reinsurance $_{t}$ & Liquidity creation ratio $_{\mathrm{t}}$ \\
\hline Demand of reinsurance $t-1$ & $\begin{array}{c}0.6906 \\
(0.000)\end{array}$ & $\begin{array}{c}0.0129 \\
(0.020)\end{array}$ \\
\hline Liquidity creation ratio $\mathrm{t}-1$ & $\begin{array}{c}0.1053 \\
(0.000)\end{array}$ & $\begin{array}{r}0.6627 \\
(0.000)\end{array}$ \\
\hline Insurance leverage & $\begin{array}{c}0.0105 \\
(0.000)\end{array}$ & \\
\hline Geographical concentration & $\begin{array}{l}-0.0364 \\
(0.000)\end{array}$ & $\begin{array}{l}-0.0098 \\
(0.179)\end{array}$ \\
\hline Regulatory pressure & $\begin{array}{l}-0.0769 \\
(0.000)\end{array}$ & $\begin{array}{c}0.0962 \\
(0.000)\end{array}$ \\
\hline Liabilities & $\begin{array}{r}0.0248 \\
(0.000)\end{array}$ & \\
\hline Line concentration & $\begin{array}{l}-0.0717 \\
(0.000)\end{array}$ & $\begin{array}{l}-0.0389 \\
(0.000)\end{array}$ \\
\hline Reinsurance price & $\begin{array}{l}-0.0101 \\
(0.000)\end{array}$ & $\begin{array}{c}0.0051 \\
(0.000)\end{array}$ \\
\hline Tax exemption & $\begin{array}{c}0.0018 \\
(0.729)\end{array}$ & $\begin{array}{l}-0.0131 \\
(0.006)\end{array}$ \\
\hline Information asymmetry & $\begin{array}{r}0.0255 \\
(0.004)\end{array}$ & $\begin{array}{r}0.0125 \\
(0.165)\end{array}$ \\
\hline Loss development & $\begin{array}{l}-0.0001 \\
(0.287)\end{array}$ & $\begin{array}{r}0.0000 \\
(0.935)\end{array}$ \\
\hline New York license & $\begin{array}{c}0.0282 \\
(0.000)\end{array}$ & $\begin{array}{l}-0.0069 \\
(0.151)\end{array}$ \\
\hline Cost of capital & $\begin{array}{l}-0.0195 \\
(0.052)\end{array}$ & $\begin{array}{l}-0.0771 \\
(0.000)\end{array}$ \\
\hline Firm size & $\begin{array}{l}-0.0093 \\
(0.000)\end{array}$ & $\begin{array}{r}0.0164 \\
(0.000)\end{array}$ \\
\hline Group affiliation & $\begin{array}{c}0.0215 \\
(0.000)\end{array}$ & $\begin{array}{l}-0.0066 \\
(0.125)\end{array}$ \\
\hline Mix concentration & $\begin{array}{c}0.0096 \\
(0.494)\end{array}$ & $\begin{array}{l}-0.0052 \\
(0.621)\end{array}$ \\
\hline Capital & $\begin{array}{r}0.2025 \\
(0.000) \\
\end{array}$ & \\
\hline Number of observations & 30,753 & 30,753 \\
\hline Number of firms & 2,658 & 2,658 \\
\hline R-Square (within) & 0.5648 & 0.5863 \\
\hline
\end{tabular}




\section{Table 5a - Large insurers: Demand for reinsurance and liquidity creation with Generalized Method of Moments}

This table presents the coefficients and $p$-values obtained from the GMM method of estimation. Robust standard errors are used to obtain confidence intervals and the corresponding $p$-values are reported in parentheses. It also documents the $p$-value of the specification J-test. The standard GMM is rejected at all significance levels. Control variables are defined in Table 2.

\begin{tabular}{|c|c|c|c|c|c|c|}
\hline \multirow[b]{2}{*}{ Variable } & \multicolumn{2}{|c|}{ Standard GMM } & \multicolumn{2}{|c|}{$\begin{array}{c}\text { Tikhonov regularized } \\
\text { GMM }\end{array}$} & \multicolumn{2}{|c|}{$\begin{array}{l}\text { Landweber-Fridman } \\
\text { regularized GMM }\end{array}$} \\
\hline & Reins & Liquid & Reins & Liquid & Reins & Liquid \\
\hline Demand for reinsurance $_{t-1}$ & $\begin{array}{r}0.9147 \\
(0.000)\end{array}$ & $\begin{array}{c}0.0035 \\
(0.2023)\end{array}$ & $\begin{array}{c}0.8679 \\
(0.000)\end{array}$ & $\begin{array}{l}-0.0516 \\
(0.4236)\end{array}$ & $\begin{array}{c}0.8693 \\
(0.000)\end{array}$ & $\begin{array}{l}-0.0468 \\
(0.4140)\end{array}$ \\
\hline Liquidity creation ratio ${ }_{t-1}$ & $\begin{array}{c}0.0574 \\
(0.2512)\end{array}$ & $\begin{array}{c}0.7562 \\
(0.000)\end{array}$ & $\begin{array}{c}0.0380 \\
(0.1711)\end{array}$ & $\begin{array}{r}0.6057 \\
(0.000)\end{array}$ & $\begin{array}{c}0.0225 \\
(0.2813)\end{array}$ & $\begin{array}{r}0.6022 \\
(0.000)\end{array}$ \\
\hline Insurance leverage & $\begin{array}{l}0.0095 \\
(0.000)\end{array}$ & & $\begin{array}{r}0.0169 \\
(0.000)\end{array}$ & & $\begin{array}{r}0.0021 \\
(0.000)\end{array}$ & \\
\hline Geographical concentration & $\begin{array}{l}-0.0204 \\
(0.000)\end{array}$ & $\begin{array}{l}-0.0780 \\
(0.000)\end{array}$ & $\begin{array}{l}-0.0067 \\
(0.000)\end{array}$ & $\begin{array}{l}-0.0232 \\
(0.000)\end{array}$ & $\begin{array}{l}-0.0063 \\
(0.000)\end{array}$ & $\begin{array}{l}-0.0463 \\
(0.000)\end{array}$ \\
\hline Regulatory pressure & $\begin{array}{c}0.0011 \\
(0.4193)\end{array}$ & $\begin{array}{c}0.0248 \\
(0.2758)\end{array}$ & $\begin{array}{c}0.0115 \\
(0.326)\end{array}$ & $\begin{array}{c}0.0531 \\
(0.1885)\end{array}$ & $\begin{array}{c}0.0178 \\
(0.289)\end{array}$ & $\begin{array}{c}0.0571 \\
(0.0874)\end{array}$ \\
\hline Liabilities & $\begin{array}{c}0.0066 \\
(0.250)\end{array}$ & & $\begin{array}{r}0.0181 \\
(0.145)\end{array}$ & & $\begin{array}{c}0.012 \\
(0.109)\end{array}$ & \\
\hline Line concentration & $\begin{array}{l}-0.0269 \\
(0.000)\end{array}$ & $\begin{array}{c}0.0134 \\
(0.1743)\end{array}$ & $\begin{array}{l}-0.0427 \\
(0.000)\end{array}$ & $\begin{array}{c}0.0397 \\
(0.1658)\end{array}$ & $\begin{array}{l}-0.0580 \\
(0.000)\end{array}$ & $\begin{array}{c}0.0313 \\
(0.1663)\end{array}$ \\
\hline Reinsurance price & $\begin{array}{l}-5.4 \mathrm{E}-4 \\
(0.1381)\end{array}$ & $\begin{array}{l}-3.64 \mathrm{E}-4 \\
(0.1841)\end{array}$ & $\begin{array}{l}-3.67 \mathrm{E}-4 \\
(0.000)\end{array}$ & $\begin{array}{l}-5.6 \mathrm{E}-4 \\
(0.1366)\end{array}$ & $\begin{array}{l}-0.0045 \\
(0.000)\end{array}$ & $\begin{array}{l}-2.65 E-4 \\
(0.2357)\end{array}$ \\
\hline Tax exemption & $\begin{array}{c}0.0079 \\
(0.105)\end{array}$ & $\begin{array}{c}0.0030 \\
(0.1243)\end{array}$ & $\begin{array}{c}0.003 \\
(0.245)\end{array}$ & $\begin{array}{l}0.005 \\
(0.1056)\end{array}$ & $\begin{array}{l}0.0025 \\
(0.325)\end{array}$ & $\begin{array}{l}0.002 \\
(0.2660)\end{array}$ \\
\hline Information asymmetry & $\begin{array}{l}-0.0162 \\
(0.4432)\end{array}$ & $\begin{array}{c}0.0546 \\
(0.000)\end{array}$ & $\begin{array}{l}-0.0401 \\
(0.189)\end{array}$ & $\begin{array}{c}0.010 \\
(0.000)\end{array}$ & $\begin{array}{l}-0.0503 \\
(0.207)\end{array}$ & $\begin{array}{c}0.02 \\
(0.000)\end{array}$ \\
\hline Loss development & $\begin{array}{l}-1.57 \mathrm{E}-4 \\
(0.3523)\end{array}$ & $\begin{array}{l}-0.0045 \\
(0.3102)\end{array}$ & $\begin{array}{l}-8.9 E-4 \\
(0.532)\end{array}$ & $\begin{array}{l}-0.0047 \\
(0.1270)\end{array}$ & $\begin{array}{l}-0.001 \\
(0.294)\end{array}$ & $\begin{array}{l}-0.002 \\
(0.3170)\end{array}$ \\
\hline New York license & $\begin{array}{l}-0.0038 \\
(0.0228)\end{array}$ & $\begin{array}{c}1.6 \mathrm{E}-4 \\
(0.3102)\end{array}$ & $\begin{array}{l}-0.0339 \\
(0.000)\end{array}$ & $\begin{array}{r}1.98 \mathrm{E}-4 \\
(0.1884)\end{array}$ & $\begin{array}{l}-0.0415 \\
(0.000)\end{array}$ & $\begin{array}{r}4.69 \mathrm{E}-4 \\
(0.3953)\end{array}$ \\
\hline Cost of capital & $\begin{array}{c}0.0079 \\
(0.1525)\end{array}$ & $\begin{array}{c}0.0038 \\
(0.1026)\end{array}$ & $\begin{array}{c}0.0478 \\
(0.119)\end{array}$ & $\begin{array}{c}0.0258 \\
(0.1741)\end{array}$ & $\begin{array}{c}0.0388 \\
(0.208)\end{array}$ & $\begin{array}{c}0.0234 \\
(0.1931)\end{array}$ \\
\hline Firm size & $\begin{array}{c}0.0051 \\
(0.512)\end{array}$ & $\begin{array}{l}-0.0021 \\
(0.3694)\end{array}$ & $\begin{array}{c}0.002 \\
(0.478)\end{array}$ & $\begin{array}{l}-0.0130 \\
(0.4355)\end{array}$ & $\begin{array}{c}0.0065 \\
(0.1246)\end{array}$ & $\begin{array}{l}-0.0100 \\
(0.4252)\end{array}$ \\
\hline Group affiliation & $\begin{array}{c}0.0280 \\
(0.2623)\end{array}$ & $\begin{array}{l}-0.0027 \\
(0.0885)\end{array}$ & $\begin{array}{c}0.046 \\
(0.136)\end{array}$ & $\begin{array}{l}-0.0059 \\
(0.3694)\end{array}$ & $\begin{array}{c}0.0491 \\
(0.179)\end{array}$ & $\begin{array}{l}-0.0125 \\
(0.3480)\end{array}$ \\
\hline Mix concentration & $\begin{array}{c}\text { 8.57E-4 } \\
(1.000)\end{array}$ & $\begin{array}{c}0.0076 \\
(0.1319)\end{array}$ & $\begin{array}{r}0.0107 \\
(0.000)\end{array}$ & $\begin{array}{c}0.0520 \\
(0.1492)\end{array}$ & $\begin{array}{c}0.0216 \\
(0.000)\end{array}$ & $\begin{array}{c}0.020 \\
(0.3085)\end{array}$ \\
\hline Capital & $\begin{array}{c}0.0375 \\
(0.000) \\
\end{array}$ & & $\begin{array}{c}0.1610 \\
(0.000)\end{array}$ & & $\begin{array}{c}0.182 \\
(0.000)\end{array}$ & \\
\hline$p$-value of the $\mathrm{J}$-test & 0.0000 & 0.0000 & 0.2058 & 0.2568 & 0.5436 & 0.4602 \\
\hline Number of observations & & & & & & \\
\hline Number of firms & & & & & & \\
\hline
\end{tabular}


Table 5b: Medium insurers Demand for reinsurance and liquidity creation ratio with Generalized Method of Moments

This table presents the coefficients and $p$-values obtained from the GMM method of estimation. Robust standard errors are used to obtain confidence intervals and the corresponding $p$-values are reported in parentheses. It also documents the $p$-value of the specification J-test. The standard GMM is rejected at all significance levels. Control variables are defined in Table 2.

\begin{tabular}{|c|c|c|c|c|c|c|}
\hline \multirow[b]{2}{*}{ Variable } & \multicolumn{2}{|c|}{ Standard GMM } & \multicolumn{2}{|c|}{$\begin{array}{c}\text { Tikhonov regularized } \\
\text { GMM }\end{array}$} & \multicolumn{2}{|c|}{$\begin{array}{l}\text { Landweber-Fridman } \\
\text { regularized GMM }\end{array}$} \\
\hline & Reins & Liquid & Reins & Liquid & Reins & Liquid \\
\hline Demand for reinsurance $t-1$ & $\begin{array}{l}0.8420 \\
(0.000)\end{array}$ & $\begin{array}{c}0.0124 \\
(0.2525)\end{array}$ & $\begin{array}{r}0.7867 \\
(0.000)\end{array}$ & $\begin{array}{c}0.0393 \\
(0.4483)\end{array}$ & $\begin{array}{c}0.7198 \\
(0.000)\end{array}$ & $\begin{array}{c}0.0201 \\
(0.2525)\end{array}$ \\
\hline Liquidity creation ratio ${ }_{t-1}$ & $\begin{array}{c}0.0492 \\
(0.000)\end{array}$ & $\begin{array}{c}0.8074 \\
(0.000)\end{array}$ & $\begin{array}{c}0.118 \\
(0.000)\end{array}$ & $\begin{array}{c}0.6724 \\
(0.000)\end{array}$ & $\begin{array}{c}0.1535 \\
(0.000)\end{array}$ & $\begin{array}{c}0.7458 \\
(0.000)\end{array}$ \\
\hline Insurance leverage & $\begin{array}{c}0.003 \\
(0.000)\end{array}$ & & $\begin{array}{c}0.002 \\
(0.000)\end{array}$ & & $\begin{array}{c}0.0045 \\
(0.000)\end{array}$ & \\
\hline Geographical concentration & $\begin{array}{l}-0.0039 \\
(0.045)\end{array}$ & $\begin{array}{l}-0.0046 \\
(0.1479)\end{array}$ & $\begin{array}{l}-0.0438 \\
(0.109)\end{array}$ & $\begin{array}{c}0.0200 \\
(0.4013)\end{array}$ & $\begin{array}{l}-0.0658 \\
(0.163)\end{array}$ & $\begin{array}{c}0.0100 \\
(0.4432)\end{array}$ \\
\hline Regulatory pressure & $\begin{array}{l}-0.00642 \\
(0.1136)\end{array}$ & $\begin{array}{r}0.0447 \\
(0.000)\end{array}$ & $\begin{array}{l}-0.040 \\
(0.4191)\end{array}$ & $\begin{array}{c}0.0188 \\
(0.000)\end{array}$ & $\begin{array}{l}-0.0479 \\
(0.1690)\end{array}$ & $\begin{array}{r}0.0200 \\
(0.000)\end{array}$ \\
\hline Liabilities & $\begin{array}{l}6.6 \mathrm{E}-5 \\
(0.4854)\end{array}$ & & $\begin{array}{c}0.0018 \\
(0.1841)\end{array}$ & & $\begin{array}{c}0.0038 \\
(0.2408)\end{array}$ & \\
\hline Line concentration & $\begin{array}{c}0.0031 \\
(0.2405)\end{array}$ & $\begin{array}{c}6.04 \mathrm{E}-4 \\
(0.3336)\end{array}$ & $\begin{array}{c}0.0296 \\
(0.225)\end{array}$ & $\begin{array}{c}0.0185 \\
(0.2204)\end{array}$ & $\begin{array}{c}0.0101 \\
(0.4207)\end{array}$ & $\begin{array}{c}0.0256 \\
(0.0968)\end{array}$ \\
\hline Reinsurance price & $\begin{array}{l}-0.001 \\
(0.1587)\end{array}$ & $\begin{array}{r}0.0027 \\
(0.000)\end{array}$ & $\begin{array}{l}-0.0346 \\
(0.000)\end{array}$ & $\begin{array}{c}0.0062 \\
(0.000)\end{array}$ & $\begin{array}{l}-0.0041 \\
(0.000)\end{array}$ & $\begin{array}{r}0.0090 \\
(0.000)\end{array}$ \\
\hline Tax exemption & $\begin{array}{l}-0.0237 \\
(0.2057)\end{array}$ & $\begin{array}{c}0.0019 \\
(0.1456)\end{array}$ & $\begin{array}{l}-0.006 \\
(0.435)\end{array}$ & $\begin{array}{c}0.0475 \\
(0.0959)\end{array}$ & $\begin{array}{l}-0.0122 \\
(0.375)\end{array}$ & $\begin{array}{c}0.0200 \\
(0.2119)\end{array}$ \\
\hline Information asymmetry & $\begin{array}{c}0.0605 \\
(0.1760)\end{array}$ & $\begin{array}{c}0.0133 \\
(0.3698)\end{array}$ & $\begin{array}{c}0.0703 \\
(0.194)\end{array}$ & $\begin{array}{c}0.0342 \\
(0.2929)\end{array}$ & $\begin{array}{c}0.0533 \\
(0.1885)\end{array}$ & $\begin{array}{c}0.0200 \\
(0.3284)\end{array}$ \\
\hline Loss development & $\begin{array}{l}-6.02 E-5 \\
(0.0668)\end{array}$ & $\begin{array}{c}0.0013 \\
(0.2222)\end{array}$ & $\begin{array}{l}-1.2 \mathrm{E}-5 \\
(0.1151)\end{array}$ & $\begin{array}{c}0.002 \\
(0.000)\end{array}$ & $\begin{array}{l}-3.12 \mathrm{E}-5 \\
(0.1186)\end{array}$ & $\begin{array}{c}0.0012 \\
(0.000)\end{array}$ \\
\hline New York license & $\begin{array}{c}0.0126 \\
(0.000)\end{array}$ & $\begin{array}{c}4.096 \mathrm{E}-5 \\
(0.1587)\end{array}$ & $\begin{array}{c}0.0124 \\
(0.000)\end{array}$ & $\begin{array}{c}1.67 \mathrm{E}-4 \\
(0.2019)\end{array}$ & $\begin{array}{c}0.0134 \\
(0.000)\end{array}$ & $\begin{array}{c}2.2 \mathrm{E}-4 \\
(0.1357)\end{array}$ \\
\hline Cost of capital & $\begin{array}{c}0.0647 \\
(0.1733)\end{array}$ & $\begin{array}{l}-0.0029 \\
(0.1669)\end{array}$ & $\begin{array}{c}0.0107 \\
(0.1587)\end{array}$ & $\begin{array}{l}-0.009 \\
(0.2893)\end{array}$ & $\begin{array}{c}0.0280 \\
(0.384)\end{array}$ & $\begin{array}{l}-0.004 \\
(0.3875)\end{array}$ \\
\hline Firm size & $\begin{array}{l}-0.0021 \\
(0.228)\end{array}$ & $\begin{array}{c}0.0372 \\
(0.000)\end{array}$ & $\begin{array}{l}-0.0017 \\
(0.1977)\end{array}$ & $\begin{array}{c}0.02 \\
(0.000)\end{array}$ & $\begin{array}{l}-0.0095 \\
(0.129)\end{array}$ & $\begin{array}{c}0.02 \\
(0.000)\end{array}$ \\
\hline Firm affiliation & $\begin{array}{c}0.0065 \\
(0.0923)\end{array}$ & $\begin{array}{c}0.0043 \\
(0.000)\end{array}$ & $\begin{array}{c}0.0385 \\
(0.236)\end{array}$ & $\begin{array}{c}0.006 \\
(0.000)\end{array}$ & $\begin{array}{c}0.0280 \\
(0.2575)\end{array}$ & $\begin{array}{c}0.002 \\
(0.000)\end{array}$ \\
\hline Mix concentration & $\begin{array}{l}-0.0185 \\
(0.3621)\end{array}$ & $\begin{array}{l}-0.0170 \\
(0.1725)\end{array}$ & $\begin{array}{l}-0.0433 \\
(0.1481)\end{array}$ & $\begin{array}{l}-0.0266 \\
(0.1876)\end{array}$ & $\begin{array}{l}-0.0251 \\
(0.3332)\end{array}$ & $\begin{array}{l}-0.0214 \\
(0.2266)\end{array}$ \\
\hline Capital & $\begin{array}{c}0.0204 \\
(0.000)\end{array}$ & & $\begin{array}{c}0.1391 \\
(0.000)\end{array}$ & & $\begin{array}{c}0.2123 \\
(0.000)\end{array}$ & \\
\hline$p$-value of the J-test & 0.0000 & 0.0000 & 0.2012 & 0.1372 & 0.2528 & 0.2537 \\
\hline Number of observations & & & & & & \\
\hline Number of firms & & & & & & \\
\hline
\end{tabular}




\section{Table 5c: Small insurers}

Demand for reinsurance and liquidity creation ratio with Generalized Method of Moments

This table presents the coefficients and $p$-values obtained from the GMM method of estimation. Robust standard errors are used to obtain confidence intervals and the corresponding $p$-values are reported in parentheses. It also documents the $p$-value of the specification J-test. The standard GMM is rejected at all significance levels. Control variables are defined in Table 2.

\begin{tabular}{|c|c|c|c|c|c|c|}
\hline \multirow[b]{2}{*}{ Variable } & \multicolumn{2}{|c|}{ Standard GMM } & \multicolumn{2}{|c|}{$\begin{array}{c}\text { Tikhonov regularized } \\
\text { GMM }\end{array}$} & \multicolumn{2}{|c|}{$\begin{array}{l}\text { Landweber-Fridman } \\
\text { regularized GMM }\end{array}$} \\
\hline & Reins & Liquid & Reins & Liquid & Reins & Liquid \\
\hline Demand for reinsurance $t-1$ & $\begin{array}{c}0.8142 \\
(0.000)\end{array}$ & $\begin{array}{r}0.0074 \\
(0.000)\end{array}$ & $\begin{array}{c}0.7409 \\
(0.000)\end{array}$ & $\begin{array}{c}0.010 \\
(0.000)\end{array}$ & $\begin{array}{c}0.6881 \\
(0.000)\end{array}$ & $\begin{array}{r}0.0411 \\
(0.000)\end{array}$ \\
\hline Liquidity creation ratio ${ }_{t-1}$ & $\begin{array}{r}0.0147 \\
(0.000)\end{array}$ & $\begin{array}{r}0.8140 \\
(0.000)\end{array}$ & $\begin{array}{c}0.0343 \\
(0.000)\end{array}$ & $\begin{array}{c}0.8041 \\
(0.000)\end{array}$ & $\begin{array}{c}0.0289 \\
(0.000)\end{array}$ & $\begin{array}{c}0.8095 \\
(0.000)\end{array}$ \\
\hline Insurance leverage & $\begin{array}{c}0.0028 \\
(0.000)\end{array}$ & & $\begin{array}{r}0.0077 \\
(0.000)\end{array}$ & & $\begin{array}{r}0.0123 \\
(0.000)\end{array}$ & \\
\hline Geographical concentration & $\begin{array}{l}-0.0029 \\
(0.000)\end{array}$ & $\begin{array}{l}-0.0167 \\
(0.4389)\end{array}$ & $\begin{array}{l}-0.0645 \\
(0.000)\end{array}$ & $\begin{array}{l}-0.0376 \\
(0.3108)\end{array}$ & $\begin{array}{l}-0.0458 \\
(0.000)\end{array}$ & $\begin{array}{l}-0.012 \\
(0.3694)\end{array}$ \\
\hline Regulatory pressure & $\begin{array}{l}-0.0160 \\
(0.000)\end{array}$ & $\begin{array}{r}0.0317 \\
(0.000)\end{array}$ & $\begin{array}{l}-0.0164 \\
(0.000)\end{array}$ & $\begin{array}{c}0.0592 \\
(0.000)\end{array}$ & $\begin{array}{l}-0.0124 \\
(0.000)\end{array}$ & $\begin{array}{c}0.0210 \\
(0.000)\end{array}$ \\
\hline Liabilities & $\begin{array}{c}2.7 \mathrm{E}-4 \\
(0.3499)\end{array}$ & & $\begin{array}{c}0.0378 \\
(0.000)\end{array}$ & & $\begin{array}{c}0.0303 \\
(0.000)\end{array}$ & \\
\hline Line concentration & $\begin{array}{l}-0.0097 \\
(0.000)\end{array}$ & $\begin{array}{l}-0.0032 \\
(0.000)\end{array}$ & $\begin{array}{l}-0.0390 \\
(0.000)\end{array}$ & $\begin{array}{l}-0.0483 \\
(0.000)\end{array}$ & $\begin{array}{l}-0.0668 \\
(0.000)\end{array}$ & $\begin{array}{l}-0.0433 \\
(0.000)\end{array}$ \\
\hline Reinsurance price & $\begin{array}{l}-0.0012 \\
(0.000)\end{array}$ & $\begin{array}{r}0.0016 \\
(0.000)\end{array}$ & $\begin{array}{l}-0.004 \\
(0.000)\end{array}$ & $\begin{array}{c}0.0081 \\
(0.000)\end{array}$ & $\begin{array}{l}-0.0086 \\
(0.000)\end{array}$ & $\begin{array}{c}0.0084 \\
(0.000)\end{array}$ \\
\hline Tax exemption & $\begin{array}{c}0.0085 \\
(0.1440)\end{array}$ & $\begin{array}{l}-0.0042 \\
(0.000)\end{array}$ & $\begin{array}{c}0.0339 \\
(0.1357)\end{array}$ & $\begin{array}{l}-0.0312 \\
(0.000)\end{array}$ & $\begin{array}{c}0.0173 \\
(0.2566)\end{array}$ & $\begin{array}{l}-0.0158 \\
(0.000)\end{array}$ \\
\hline Information asymmetry & $\begin{array}{c}0.0068 \\
(0.000)\end{array}$ & $\begin{array}{c}0.0267 \\
(0.4120)\end{array}$ & $\begin{array}{c}0.0200 \\
(0.000)\end{array}$ & $\begin{array}{l}-0.0100 \\
(0.4310)\end{array}$ & $\begin{array}{c}0.0462 \\
(0.000)\end{array}$ & $\begin{array}{l}-0.016 \\
(0.2119)\end{array}$ \\
\hline Loss development & $\begin{array}{l}-3.2 \mathrm{E}-6 \\
(0.372)\end{array}$ & $\begin{array}{c}0.0118 \\
(0.4136)\end{array}$ & $\begin{array}{l}-0.002 \\
(0.1587)\end{array}$ & $\begin{array}{l}-0.0337 \\
(0.2035)\end{array}$ & $\begin{array}{l}-0.001 \\
(0.1587)\end{array}$ & $\begin{array}{l}-0.0120 \\
(0.2638)\end{array}$ \\
\hline New York license & $\begin{array}{c}0.010 \\
(0.000)\end{array}$ & $\begin{array}{l}-9.41 \mathrm{E}-5 \\
(0.1303)\end{array}$ & $\begin{array}{c}0.0240 \\
(0.000)\end{array}$ & $\begin{array}{l}-2.9 \mathrm{E}-4 \\
(0.3813)\end{array}$ & $\begin{array}{c}0.0465 \\
(0.000)\end{array}$ & $\begin{array}{l}-2.3 E-4 \\
(0.3468)\end{array}$ \\
\hline Cost of capital & $\begin{array}{l}-0.0159 \\
(0.000)\end{array}$ & $\begin{array}{l}-0.0024 \\
(0.000)\end{array}$ & $\begin{array}{l}-0.0748 \\
(0.000)\end{array}$ & $\begin{array}{l}-0.020 \\
(0.0401)\end{array}$ & $\begin{array}{l}-0.0599 \\
(0.000)\end{array}$ & $\begin{array}{l}-0.010 \\
(0.000)\end{array}$ \\
\hline Firm size & $\begin{array}{l}-0.0026 \\
(0.000)\end{array}$ & $\begin{array}{c}0.0225 \\
(0.000)\end{array}$ & $\begin{array}{l}-0.0032 \\
(0.000)\end{array}$ & $\begin{array}{c}0.0023 \\
(0.000)\end{array}$ & $\begin{array}{l}-0.002 \\
(0.000)\end{array}$ & $\begin{array}{c}0.00204 \\
(0.000)\end{array}$ \\
\hline Group affiliation & $\begin{array}{c}0.0173 \\
(0.000)\end{array}$ & $\begin{array}{l}-0.0037 \\
(0.1775)\end{array}$ & $\begin{array}{c}0.0601 \\
(0.000)\end{array}$ & $\begin{array}{l}-0.0030 \\
(0.4503)\end{array}$ & $\begin{array}{c}0.0753 \\
(0.000)\end{array}$ & $\begin{array}{l}-0.004 \\
(0.3792)\end{array}$ \\
\hline Mix concentration & $\begin{array}{c}0.0073 \\
(0.1233)\end{array}$ & $\begin{array}{l}-0.004 \\
(0.1279)\end{array}$ & $\begin{array}{c}0.0169 \\
(0.1977)\end{array}$ & $\begin{array}{l}-0.0353 \\
(0.4415)\end{array}$ & $\begin{array}{c}0.01726 \\
(0.3354)\end{array}$ & $\begin{array}{l}-0.0498 \\
(0.3254)\end{array}$ \\
\hline Capital & $\begin{array}{c}0.0345 \\
(0.000)\end{array}$ & & $\begin{array}{c}0.215 \\
(0.000)\end{array}$ & & $\begin{array}{c}0.1630 \\
(0.000)\end{array}$ & \\
\hline$p$-value of the J-test & 0.0000 & 0.0000 & 0.2219 & 0.1820 & 0.4487 & 0.2597 \\
\hline Number of observations & & & & & & \\
\hline Number of firms & & & & & & \\
\hline
\end{tabular}




\section{Table 6a: Test of exogeneity for ML-SEM model}

All firms in shorter sub-periods during the 1992-2014 period.

p-values for the test: $H_{0}: \phi_{j k}=0$ are reported. Variables are defined in Table 2.

\begin{tabular}{l|cc|cc|cc}
\hline \multicolumn{1}{c|}{ Variable } & \multicolumn{2}{c|}{$1992-1999$} & \multicolumn{2}{c|}{$2000-2007$} & \multicolumn{2}{c}{$2008-2014$} \\
& Reins $_{\mathrm{t}}$ & Liquid $_{\mathrm{t}}$ & Reins $_{\mathrm{t}}$ & Liquid $_{\mathrm{t}}$ & Reins $_{\mathrm{t}}$ & Liquid $_{\mathrm{t}}$ \\
\hline At time & & & & & \\
Insurance leverage $_{\mathrm{t}+1}$ & & & & & & \\
Regulatory pressure $_{\mathrm{t}+1}$ & 0.007 & & 0.001 & & 0.168 & \\
Reinsurance price $_{\mathrm{t}+1}$ & 0.201 & 0.000 & 0.012 & 0.036 & 0.009 & 0.155 \\
Cost of capital $_{\mathrm{t}+1}$ & 0.093 & 0.002 & 0.036 & 0.001 & 0.013 & 0.082 \\
Tax exemption $_{\mathrm{t}+1}$ & & 0.075 & & 0.111 & & 0.434 \\
Information asymmetry $_{\mathrm{t}+1}$ & 0.069 & 0.004 & 0.838 & 0.942 & 0.883 & 0.018 \\
Capital $_{\mathrm{t}+1}$ & & 0.000 & & 0.000 & & 0.000 \\
\hline
\end{tabular}




\section{Table 9a: Estimations for the ML-SME model in different periods}

For all insurers during the 1992-2014 period. Non-standardized data. All goodness of fit measures have acceptable values. The Satorra-Bentler (SB) scaled test is robust to nonnormality. Robust standard errors are used to obtain confidence intervals and the corresponding $p$-values are reported in parentheses. Control variables are defined in Table 2 and their tests of exogeneity is documented in Table 6a.

\begin{tabular}{|c|c|c|c|c|c|c|}
\hline \multirow[b]{2}{*}{ Variable } & \multicolumn{2}{|c|}{ 1992-1999 } & \multicolumn{2}{|c|}{$2000-2007$} & \multicolumn{2}{|c|}{$2008-2014$} \\
\hline & Reins $_{t}$ & Liquid $_{\mathrm{t}}$ & Reins $_{\mathrm{t}}$ & Liquid $_{\mathrm{t}}$ & Reins $_{t}$ & Liquid $_{t}$ \\
\hline \multirow[t]{2}{*}{ Reins $_{t-1}$} & 0.7974 & 0.1968 & 0.7973 & 0.0683 & 0.7973 & 0.1242 \\
\hline & $(0.000)$ & $(0.000)$ & $(0.000)$ & $(0.010)$ & $(0.000)$ & $(0.000)$ \\
\hline \multirow[t]{2}{*}{ Liquid $_{\mathrm{t}-1}$} & 0.2103 & 0.8649 & 0.0872 & 0.7285 & 0.0809 & 0.6991 \\
\hline & $(0.000)$ & $(0.000)$ & $(0.000)$ & $(0.000)$ & $(0.000)$ & $(0.000)$ \\
\hline \multirow[t]{2}{*}{ Insurance leverage $_{t}$} & 0.1200 & & 0.1343 & & 0.0786 & \\
\hline & $(0.002)$ & & $(0.000)$ & & $(0.001)$ & \\
\hline \multirow[t]{2}{*}{ Regulatory pressure $_{t}$} & -0.0357 & 0.0555 & -0.0431 & 0.0907 & -0.0367 & 0.0421 \\
\hline & $(0.000)$ & $(0.000)$ & $(0.000)$ & $(0.000)$ & $(0.011)$ & $(0.000)$ \\
\hline \multirow[t]{2}{*}{ Reinsurance price $_{t}$} & -0.0389 & 0.0106 & -0.0599 & -0.0020 & -0.0400 & -0.0284 \\
\hline & $(0.000)$ & $(0.415)$ & $(0.000)$ & $(0.893)$ & $(0.000)$ & $(0.018)$ \\
\hline \multirow[t]{2}{*}{ Cost of capital $t$} & & -0.0285 & & -0.0298 & & -0.0222 \\
\hline & & $(0.138)$ & & $(0.040)$ & & $(0.069)$ \\
\hline \multirow[t]{2}{*}{ Tax exemption $_{t}$} & 0.0217 & 0.0080 & 0.0081 & 0.0416 & 0.0183 & -0.0216 \\
\hline & $(0.359)$ & $(0.747)$ & $(0.459)$ & $(0.003)$ & $(0.069)$ & $(0.479)$ \\
\hline \multirow[t]{2}{*}{ Information asymmetry t } & & -0.0135 & & -0.0175 & & 0.0174 \\
\hline & & $(0.390)$ & & $(0.305)$ & & $(0.273)$ \\
\hline \multirow[t]{2}{*}{ Capital $_{\mathrm{t}}$} & 0.2001 & & 0.0969 & & 0.0942 & \\
\hline & $(0.000)$ & & $(0.001)$ & & $(0.000)$ & \\
\hline Number of firms & 1,072 & & 1,063 & & 1,108 & \\
\hline \multicolumn{7}{|l|}{ Goodness of Fit Model } \\
\hline RMSEA_SB & 0.033 & 0.027 & 0.025 & 0.035 & 0.022 & 0.039 \\
\hline CFI_SB & 0.979 & 0.987 & 0.989 & 0.968 & 0.992 & 0.974 \\
\hline TLI_SB & 0.961 & 0.973 & 0.981 & 0.946 & 0.988 & 0.954 \\
\hline SRMR & 0.007 & 0.010 & 0.007 & 0.012 & 0.005 & 0.010 \\
\hline
\end{tabular}




\section{Table 9b: Standard GMM Estimation for different periods}

This table presents the coefficients and $p$-values obtained for all firms from the standard GMM method of estimation. Robust standard errors are used to obtain confidence intervals and the corresponding $p$-values are reported in parentheses. It also documents the $p$-value of the specification J-test. The standard GMM is rejected at all significance levels. Control variables are defined in Table 2.

\begin{tabular}{|c|c|c|c|c|c|c|}
\hline \multirow[b]{2}{*}{ Variable } & \multicolumn{2}{|c|}{ 1992-1999 } & \multicolumn{2}{|c|}{$2000-2007$} & \multicolumn{2}{|c|}{ 2008-2014 } \\
\hline & Reins & Liquid & Reins & Liquid & Reins & Liquid \\
\hline Demand for reinsurance & $\begin{array}{c}0.9597 \\
(0.0000)\end{array}$ & $\begin{array}{c}0.0861 \\
(0.0000)\end{array}$ & $\begin{array}{c}0.9539 \\
(0.0000)\end{array}$ & $\begin{array}{c}0.0743 \\
(0.0000)\end{array}$ & $\begin{array}{c}0.9581 \\
(0.0000)\end{array}$ & $\begin{array}{c}0.081 \\
(0.0000)\end{array}$ \\
\hline Liquidity creation ratio & $\begin{array}{c}0.0152 \\
(0.0000)\end{array}$ & $\begin{array}{c}0.7780 \\
(0.0000)\end{array}$ & $\begin{array}{c}0.0025 \\
(0.0000)\end{array}$ & $\begin{array}{c}0.7804 \\
(0.0000)\end{array}$ & $\begin{array}{c}0.0045 \\
(0.1465)\end{array}$ & $\begin{array}{c}0.7562 \\
(0.0000)\end{array}$ \\
\hline Insurance leverage & $\begin{array}{c}0.0014 \\
(0.0000)\end{array}$ & & $\begin{array}{c}0.0021 \\
(0.0000)\end{array}$ & & $\begin{array}{c}0.0020 \\
(0.0000)\end{array}$ & \\
\hline Regulatory pressure & $\begin{array}{l}-0.0372 \\
(0.0000)\end{array}$ & $\begin{array}{c}0.0320 \\
(0.0000)\end{array}$ & $\begin{array}{l}-0.0255 \\
(0.0000)\end{array}$ & $\begin{array}{c}0.0156 \\
(0.0000)\end{array}$ & $\begin{array}{l}-0.0112 \\
(0.0001)\end{array}$ & $\begin{array}{c}0.0146 \\
(0.0000)\end{array}$ \\
\hline Reinsurance price & $\begin{array}{l}-0.001 \\
(0.0000)\end{array}$ & $\begin{array}{c}0.0010 \\
(0.0162)\end{array}$ & $\begin{array}{l}-0.0015 \\
(0.0000)\end{array}$ & $\begin{array}{c}0.0020 \\
(0.0967)\end{array}$ & $\begin{array}{l}-0.001 \\
(0.0008)\end{array}$ & $\begin{array}{l}-0.014 \\
(0.1204)\end{array}$ \\
\hline Cost of capital & & $\begin{array}{l}-0.0450 \\
(0.0000)\end{array}$ & & $\begin{array}{l}-0.0696 \\
(0.0000)\end{array}$ & & $\begin{array}{l}-0.0532 \\
(0.0000)\end{array}$ \\
\hline Tax exemption & $\begin{array}{c}0.0130 \\
(0.0000)\end{array}$ & $\begin{array}{c}0.0051 \\
(0.4129)\end{array}$ & $\begin{array}{c}0.0540 \\
(0.0003)\end{array}$ & $\begin{array}{c}0.0049 \\
(0.0014)\end{array}$ & $\begin{array}{c}0.0010 \\
(0.4413)\end{array}$ & $\begin{array}{c}0.0490 \\
(0.1478)\end{array}$ \\
\hline Information asymmetry & & $\begin{array}{l}-0.0032 \\
(0.0869)\end{array}$ & & $\begin{array}{l}-0.0044 \\
(0.1470)\end{array}$ & & $\begin{array}{c}0.0063 \\
(0.1784)\end{array}$ \\
\hline Capital & $\begin{array}{c}0.0013 \\
(0.6936)\end{array}$ & & $\begin{array}{c}0.0232 \\
(0.0000)\end{array}$ & & $\begin{array}{c}0.0182 \\
(0.0000)\end{array}$ & \\
\hline$p$-value of the J-test & 0.0000 & 0.0175 & 0.0000 & 0.0003 & 0.0004 & 0.0039 \\
\hline Number of firms & \multicolumn{2}{|c|}{1,072} & \multicolumn{2}{|c|}{1,063} & \multicolumn{2}{|c|}{1,108} \\
\hline
\end{tabular}




\section{Table 9c: GMM estimation with Tikhonov method for different periods}

This table presents the coefficients and $p$-values obtained for all firms from the Tikhonov GMM method of estimation. Robust standard errors are used to obtain confidence intervals and the corresponding $p$-values are reported in parentheses. It also documents the $p$-value of the specification J-test. The model is not rejected. Control variables are defined in Table 2.

\begin{tabular}{|c|c|c|c|c|c|c|}
\hline \multirow[b]{2}{*}{ Variable } & \multicolumn{2}{|c|}{ 1992-1999 } & \multicolumn{2}{|c|}{$2000-2007$} & \multicolumn{2}{|c|}{ 2008-2014 } \\
\hline & Reins & Liquid & Reins & Liquid & Reins & Liquid \\
\hline Demand for reinsurance & $\begin{array}{c}0.6754 \\
(0.0000)\end{array}$ & $\begin{array}{c}0.0980 \\
(0.0000)\end{array}$ & $\begin{array}{c}0.6774 \\
(0.0000)\end{array}$ & $\begin{array}{c}0.0708 \\
(0.0366)\end{array}$ & $\begin{array}{c}0.8419 \\
(0.0000)\end{array}$ & $\begin{array}{c}0.0654 \\
(0.0001)\end{array}$ \\
\hline Liquidity creation ratio & $\begin{array}{c}0.0619 \\
(0.0314)\end{array}$ & $\begin{array}{c}0.6375 \\
(0.0000)\end{array}$ & $\begin{array}{c}0.1220 \\
(0.0000)\end{array}$ & $\begin{array}{c}0.5659 \\
(0.0000)\end{array}$ & $\begin{array}{c}0.0338 \\
(0.0000)\end{array}$ & $\begin{array}{c}0.5832 \\
(0.0000)\end{array}$ \\
\hline Insurance leverage & $\begin{array}{c}0.0001 \\
(0.8415)\end{array}$ & & $\begin{array}{c}0.0050 \\
(0.0000)\end{array}$ & & $\begin{array}{c}0.0096 \\
(0.0000)\end{array}$ & \\
\hline Regulatory pressure & $\begin{array}{l}-0.0477 \\
(0.0000)\end{array}$ & $\begin{array}{c}0.0200 \\
(0.0000)\end{array}$ & $\begin{array}{l}-0.0486 \\
(0.0000)\end{array}$ & $\begin{array}{c}0.0468 \\
(0.0000)\end{array}$ & $\begin{array}{l}-0.1149 \\
(0.0000)\end{array}$ & $\begin{array}{r}0.05102 \\
(0.0000)\end{array}$ \\
\hline Reinsurance price & $\begin{array}{l}-0.0083 \\
(0.0000)\end{array}$ & $\begin{array}{c}0.0572 \\
(0.0000)\end{array}$ & $\begin{array}{l}-0.0022 \\
(0.0278)\end{array}$ & $\begin{array}{c}0.0402 \\
(0.437)\end{array}$ & $\begin{array}{l}-0.0055 \\
(0.0000)\end{array}$ & $\begin{array}{c}0.0363 \\
(0.4371)\end{array}$ \\
\hline Cost of capital & & $\begin{array}{l}-0.0603 \\
(0.0000)\end{array}$ & & $\begin{array}{l}-0.0530 \\
(0.0000)\end{array}$ & & $\begin{array}{l}-0.0613 \\
(0.0000)\end{array}$ \\
\hline Tax exemption & $\begin{array}{c}0.0345 \\
(0.0000)\end{array}$ & $\begin{array}{c}0.0011 \\
(0.4962)\end{array}$ & $\begin{array}{c}0.0547 \\
(0.0000)\end{array}$ & $\begin{array}{c}0.0415 \\
(0.1251)\end{array}$ & $\begin{array}{c}0.1120 \\
(0.0000)\end{array}$ & $\begin{array}{l}-0.0510 \\
(0.4251)\end{array}$ \\
\hline Information asymmetry & & $\begin{array}{l}-0.070 \\
(0.1357)\end{array}$ & & $\begin{array}{l}-0.0530 \\
(0.1212)\end{array}$ & & $\begin{array}{c}0.0105 \\
(0.5601)\end{array}$ \\
\hline Capital & $\begin{array}{c}0.0685 \\
(0.0000)\end{array}$ & & $\begin{array}{c}0.1008 \\
(0.0000)\end{array}$ & & $\begin{array}{c}0.072 \\
(0.0918)\end{array}$ & \\
\hline$p$-value of the J-test & 0.9999 & 0.9219 & 0.9821 & 0.7684 & 0.9957 & 0.5637 \\
\hline Number of firms & & & & & & 08 \\
\hline
\end{tabular}




\section{Table 9d: GMM estimation with Landweber-Fridman method for different periods}

This table presents the coefficients and $p$-values obtained for all firms from the Landweber-Fridman GMM method. Robust standard errors are used to obtain confidence intervals and the corresponding $p$-values are reported in parentheses. It also documents the $p$-value of the specification J-test. The model is not rejected. Control variables are defined in Table 2.

\begin{tabular}{|c|c|c|c|c|c|c|}
\hline \multirow[b]{2}{*}{ Variable } & \multicolumn{2}{|c|}{ 1992-1999 } & \multicolumn{2}{|c|}{$2000-2007$} & \multicolumn{2}{|c|}{$2008-2014$} \\
\hline & Reins & Liquid & Reins & Liquid & Reins & Liquid \\
\hline Demand for reinsurance & $\begin{array}{c}0.6921 \\
(0.0000)\end{array}$ & $\begin{array}{c}0.0844 \\
(0.0000)\end{array}$ & $\begin{array}{c}0.7408 \\
(0.0000)\end{array}$ & $\begin{array}{c}0.0836 \\
(0.0000)\end{array}$ & $\begin{array}{c}0.8150 \\
(0.0000)\end{array}$ & $\begin{array}{c}0.0978 \\
(0.0063)\end{array}$ \\
\hline Liquidity creation ratio & $\begin{array}{c}0.0218 \\
(0.0000)\end{array}$ & $\begin{array}{c}0.6405 \\
(0.0000)\end{array}$ & $\begin{array}{c}0.1411 \\
(0.0000)\end{array}$ & $\begin{array}{c}0.5587 \\
(0.0000)\end{array}$ & $\begin{array}{c}0.0548 \\
(0.0000)\end{array}$ & $\begin{array}{c}0.5782 \\
(0.0000)\end{array}$ \\
\hline Insurance leverage & $\begin{array}{c}0.001 \\
(0.3173)\end{array}$ & & $\begin{array}{c}0.0093 \\
(0.0000)\end{array}$ & & $\begin{array}{c}0.0111 \\
(0.0000)\end{array}$ & \\
\hline Regulatory pressure & $\begin{array}{l}-0.0550 \\
(0.0000)\end{array}$ & $\begin{array}{c}0.0200 \\
(0.0000)\end{array}$ & $\begin{array}{l}-0.0857 \\
(0.0000)\end{array}$ & $\begin{array}{c}0.0462 \\
(0.0000)\end{array}$ & $\begin{array}{c}-0.1697 \\
(0.0000)\end{array}$ & $\begin{array}{c}0.0483 \\
(0.0000)\end{array}$ \\
\hline Reinsurance price & $\begin{array}{c}-0.0156 \\
(0.0000)\end{array}$ & $\begin{array}{c}0.044 \\
(0.0000)\end{array}$ & $\begin{array}{c}-0.0073 \\
(0.0000)\end{array}$ & $\begin{array}{c}0.0302 \\
(0.5212)\end{array}$ & $\begin{array}{c}-0.0069 \\
(0.0000)\end{array}$ & $\begin{array}{c}0.0415 \\
(0.6341)\end{array}$ \\
\hline Cost of capital & & $\begin{array}{c}-0.040 \\
(0.0000)\end{array}$ & & $\begin{array}{c}-0.0502 \\
(0.0070)\end{array}$ & & $\begin{array}{c}-0.0482 \\
(0.0000)\end{array}$ \\
\hline Tax exemption & $\begin{array}{c}0.0438 \\
(0.0000)\end{array}$ & $\begin{array}{c}0.002 \\
(0.3867)\end{array}$ & $\begin{array}{c}0.0586 \\
(0.0000)\end{array}$ & $\begin{array}{r}0.0470 \\
(0.0509)\end{array}$ & $\begin{array}{c}0.0383 \\
(0.0014)\end{array}$ & $\begin{array}{r}-0.0435 \\
(0.5790)\end{array}$ \\
\hline Information asymmetry & & $\begin{array}{c}-0.040 \\
(0.1689)\end{array}$ & & $\begin{array}{c}-0.047 \\
(0.1090)\end{array}$ & & $\begin{array}{c}0.0284 \\
(0.4060)\end{array}$ \\
\hline Capital & $\begin{array}{c}0.0650 \\
(0.0000)\end{array}$ & & $\begin{array}{c}0.1739 \\
(0.0000)\end{array}$ & & $\begin{array}{c}0.0647 \\
(0.0000)\end{array}$ & \\
\hline$p$-value of the J-test & 0.9999 & 0.9996 & 0.9993 & 0.9724 & 0.9998 & 0.4987 \\
\hline Number of firms & & & & 63 & & 08 \\
\hline
\end{tabular}




\section{Table 10: OLS fixed effects summary results}

Control variables are defined in Table 2.

\begin{tabular}{|c|c|c|c|c|c|c|c|c|}
\hline \multirow[b]{2}{*}{ Variable } & \multicolumn{2}{|c|}{ All firms } & \multicolumn{2}{|c|}{ Large firms } & \multicolumn{2}{|c|}{$\begin{array}{l}\text { Medium } \\
\text { firms }\end{array}$} & \multicolumn{2}{|c|}{$\begin{array}{l}\text { Small } \\
\text { firms }\end{array}$} \\
\hline & $\mathrm{R}$ & $\mathrm{L}$ & $\mathrm{R}$ & $\mathrm{L}$ & $\mathrm{R}$ & $\mathrm{L}$ & $\mathrm{R}$ & $\mathrm{L}$ \\
\hline Reins $\mathrm{t}-1$ & + & + & + & NS & + & NS & + & $+* *$ \\
\hline Liquid $_{t-1}$ & + & + & NS & + & + & + & + & + \\
\hline Insurance leverage $_{t}$ & + & ---- & + & ---- & + & ---- & + & ---- \\
\hline $\begin{array}{l}\text { Geographical } \\
\text { concentration }_{\mathrm{t}}\end{array}$ & - & NS & - & - & NS & NS & - & NS \\
\hline Regulatory pressure $_{\mathrm{t}}$ & - & + & NS & NS & NS & + & - & + \\
\hline Liabilities $_{\mathrm{t}}$ & + & ---- & NS & ---- & NS & ---- & + & ---- \\
\hline Line concentration $_{\mathrm{t}}$ & - & - & - & NS & NS & NS & - & - \\
\hline Reinsurance price $_{t}$ & - & + & $-*$ & NS & - & NS & - & + \\
\hline Tax exemption $_{\mathrm{t}}$ & NS & - & NS & NS & NS & NS & NS & - \\
\hline Information asymmetry $\mathrm{t}$ & + & $+*$ & NS & + & NS & NS & + & NS \\
\hline Loss development $_{t}$ & NS & NS & NS & NS & NS & + & NS & NS \\
\hline New York license $_{t}$ & + & NS & - & NS & + & NS & + & NS \\
\hline Cost of capital $_{t}$ & $-*$ & - & NS & NS & NS & NS & $-*$ & - \\
\hline Firm size $_{t}$ & - & + & NS & NS & NS & + & - & + \\
\hline Group affiliation $_{\mathrm{t}}$ & + & NS & NS & NS & NS & + & + & NS \\
\hline Mix concentration $_{t}$ & NS & NS & + & NS & NS & NS & NS & NS \\
\hline Capital $_{\mathrm{t}}$ & + & ---- & + & ---- & + & ---- & + & ---- \\
\hline Number of observations & \multicolumn{2}{|c|}{34,376} & \multicolumn{2}{|c|}{1,236} & \multicolumn{2}{|c|}{1,993} & \multicolumn{2}{|c|}{30,753} \\
\hline
\end{tabular}

R: Reinsurance demand L: Liquidity creation ratio;

NS: Not significance at 10\%; $\quad * *$ Significant at 5\%; $\quad *$ Significant at $10 \% \quad \pm$ Significant at $1 \%$ 


\section{Table 11: Standard GMM summary results}

Control variables are defined in Table 2.

\begin{tabular}{|c|c|c|c|c|c|c|c|c|}
\hline \multirow[b]{2}{*}{ Variable } & \multicolumn{2}{|c|}{ All firms } & \multicolumn{2}{|c|}{ Large firms } & \multicolumn{2}{|c|}{$\begin{array}{l}\text { Medium } \\
\text { firms }\end{array}$} & \multicolumn{2}{|c|}{$\begin{array}{l}\text { Small } \\
\text { firms }\end{array}$} \\
\hline & $\mathrm{R}$ & $\mathrm{L}$ & $\mathrm{R}$ & $\mathrm{L}$ & $\mathrm{R}$ & $\mathrm{L}$ & $\mathrm{R}$ & $\mathrm{L}$ \\
\hline Reins $\mathrm{t}-1$ & + & + & + & NS & + & NS & + & + \\
\hline Liquid $_{\mathrm{t}-1}$ & + & + & NS & + & + & + & + & + \\
\hline Insurance leverage $_{t}$ & + & ---- & + & ---- & + & ---- & + & ---- \\
\hline $\begin{array}{l}\text { Geographical } \\
\text { concentration }_{t}\end{array}$ & NS & NS & - & - & $-* *$ & NS & - & NS \\
\hline Regulatory pressure $_{\mathrm{t}}$ & - & + & NS & NS & NS & + & - & + \\
\hline Liabilities $_{\mathrm{t}}$ & NS & ---- & NS & ---- & NS & ---- & NS & ---- \\
\hline Line concentration $_{t}$ & - & - & - & NS & NS & NS & - & - \\
\hline Reinsurance price $_{\mathrm{t}}$ & - & + & NS & NS & NS & + & - & + \\
\hline Tax exemption $_{t}$ & + & - & NS & NS & NS & NS & NS & - \\
\hline Information asymmetry & + & NS & NS & + & NS & NS & + & NS \\
\hline Loss development ${ }_{t}$ & + & NS & NS & NS & -* & NS & NS & NS \\
\hline New York license $_{t}$ & + & NS & - & NS & + & NS & + & NS \\
\hline Cost of capital $_{t}$ & - & - & NS & NS & NS & NS & - & - \\
\hline Firm size $_{t}$ & - & + & NS & NS & NS & + & - & + \\
\hline Group affiliation $_{\mathrm{t}}$ & + & NS & NS & $-*$ & + & + & + & NS \\
\hline Mix concentration $_{t}$ & NS & NS & NS & NS & NS & NS & NS & NS \\
\hline Capital $_{\mathrm{t}}$ & + & --- & + & ---- & + & --- & + & --- \\
\hline Number of observations & & & & & & & & \\
\hline
\end{tabular}

R: Reinsurance demand L: Liquidity creation ratio;

NS: Not significance at 10\%; $\quad * *$ Significant at 5\%; $\quad *$ Significant at $10 \% \quad \pm$ Significant at $1 \%$ 
Table 12: Landweber-Fridman regularized GMM summary results Control variables are defined in Table 2.

\begin{tabular}{|c|c|c|c|c|c|c|c|c|}
\hline \multirow[b]{2}{*}{ Variable } & \multicolumn{2}{|c|}{ All firms } & \multicolumn{2}{|c|}{ Large firms } & \multicolumn{2}{|c|}{$\begin{array}{l}\text { Medium } \\
\text { firms }\end{array}$} & \multicolumn{2}{|c|}{$\begin{array}{l}\text { Small } \\
\text { firms }\end{array}$} \\
\hline & $\mathrm{R}$ & $\mathrm{L}$ & $\mathrm{R}$ & $\mathrm{L}$ & $\mathrm{R}$ & $\mathrm{L}$ & $\mathrm{R}$ & $\mathrm{L}$ \\
\hline Reins $\mathrm{t}-1$ & + & + & + & NS & + & NS & + & + \\
\hline Liquid $_{\mathrm{t}-1}$ & + & + & NS & + & + & + & + & + \\
\hline Insurance leverage $_{t}$ & + & ---- & + & ---- & + & ---- & + & ---- \\
\hline Geographical concentration $_{\mathrm{t}}$ & - & NS & - & - & NS & NS & - & NS \\
\hline Regulatory pressure $_{\mathrm{t}}$ & - & + & NS & $+*$ & NS & + & - & + \\
\hline Liabilities $_{\mathrm{t}}$ & $+*$ & ---- & NS & ---- & NS & ---- & + & ---- \\
\hline Line concentration $_{t}$ & - & - & - & NS & NS & $+*$ & - & - \\
\hline Reinsurance price $_{t}$ & - & + & - & NS & - & + & - & + \\
\hline Tax exemption $_{\mathrm{t}}$ & + & - & NS & NS & NS & NS & NS & - \\
\hline Information asymmetry t & + & NS & NS & + & NS & NS & + & NS \\
\hline Loss development $_{\mathrm{t}}$ & $+*$ & NS & NS & NS & NS & + & NS & NS \\
\hline New York license $_{t}$ & + & NS & - & NS & + & NS & + & NS \\
\hline Cost of capital $_{t}$ & - & - & NS & NS & NS & NS & - & - \\
\hline Firm size $_{t}$ & - & + & NS & NS & NS & + & - & + \\
\hline Group affiliation $_{\mathrm{t}}$ & + & NS & NS & NS & NS & + & + & NS \\
\hline Mix concentration $_{\mathrm{t}}$ & $+*$ & NS & + & NS & NS & NS & NS & NS \\
\hline Capital $_{\mathrm{t}}$ & + & ---- & + & ---- & + & ---- & + & ---- \\
\hline Number of observations & & & & & & & & 53 \\
\hline
\end{tabular}

R: Reinsurance demand L: Liquidity creation ratio;

NS: Not significance at 10\%; $\quad * *$ Significant at 5\%; $\quad *$ Significant at $10 \% \quad \pm$ Significant at $1 \%$ 
Table 13: Tikhonov regularized GMM summary results

Control variables are defined in Table 2.

\begin{tabular}{|c|c|c|c|c|c|c|c|c|}
\hline \multirow[b]{2}{*}{ Variable } & \multicolumn{2}{|c|}{ All firms } & \multicolumn{2}{|c|}{ Large firms } & \multicolumn{2}{|c|}{$\begin{array}{l}\text { Medium } \\
\text { firms }\end{array}$} & \multicolumn{2}{|c|}{$\begin{array}{l}\text { Small } \\
\text { firms }\end{array}$} \\
\hline & $\mathrm{R}$ & $\mathrm{L}$ & $\mathrm{R}$ & $\mathrm{L}$ & $\mathrm{R}$ & $\mathrm{L}$ & $\mathrm{R}$ & $\mathrm{L}$ \\
\hline Reins $\mathrm{t}-1$ & + & + & + & NS & + & NS & + & + \\
\hline Liquid $_{\mathrm{t}-1}$ & + & + & NS & + & + & + & + & + \\
\hline Insurance leverage $_{t}$ & + & ---- & + & ---- & + & ---- & + & ---- \\
\hline Geographical concentration $_{t}$ & - & NS & - & - & NS & NS & - & NS \\
\hline Regulatory pressure $_{\mathrm{t}}$ & - & + & NS & NS & NS & + & - & + \\
\hline Liabilities $_{\mathrm{t}}$ & + & ---- & NS & ---- & NS & ---- & + & ---- \\
\hline Line concentration $_{t}$ & - & - & - & NS & NS & NS & - & - \\
\hline Reinsurance price $_{t}$ & - & + & - & NS & - & + & - & + \\
\hline Tax exemption $_{\mathrm{t}}$ & + & - & NS & NS & NS & NS & NS & - \\
\hline Information asymmetry t & + & NS & NS & + & NS & NS & + & NS \\
\hline Loss development $_{\mathrm{t}}$ & $+*$ & NS & NS & NS & NS & + & NS & NS \\
\hline New York license $_{t}$ & + & NS & - & NS & + & NS & + & NS \\
\hline Cost of capital $_{t}$ & - & - & NS & NS & NS & NS & - & $-* *$ \\
\hline Firm size $_{t}$ & - & + & NS & NS & NS & + & - & + \\
\hline Group affiliation $_{\mathrm{t}}$ & + & NS & NS & NS & NS & + & + & NS \\
\hline Mix concentration $_{\mathrm{t}}$ & NS & NS & + & NS & NS & NS & NS & NS \\
\hline Capital $_{\mathrm{t}}$ & + & ---- & + & ---- & + & ---- & + & ---- \\
\hline Number of observations & & & & & & & & 53 \\
\hline
\end{tabular}

R: Reinsurance demand L: Liquidity creation ratio;

NS: Not significance at 10\%; $\quad$ ** Significant at 5\%; $\quad *$ Significant at $10 \% \quad \pm$ Significant at $1 \%$ 